\title{
38. CENOZOIC RADIOLARIANS FROM THE BLAKE PLATEAU AND THE BLAKE-BAHAMA BASIN, DSDP LEG 44
}

\author{
Fred M. Weaver ${ }^{1}$ and Menno G. Dinkelman, Dept. of Geology, \\ Florida State University, Tallahassee, Florida
}

\section{INTRODUCTION}

Radiolarians occur in four holes drilled at three sites during DSDP Leg 44. The hole locations are listed in Table 1.

The main objectives of this study were to examine the siliceous sediments recovered during DSDP Leg 44 and to identify and discuss the relative abundances of the radiolarian taxa contained within these sediments.

We present age and zonal assignments in the summary of occurrences section and provide a complete list of the species recognized, along with literature references to each species in the following section. The biostratigraphic framework utilized in this study is from Riedel and Sanfilippo (in press) and Nigrini (1971).

\section{SUMMARY OF RADIOLARIAN OCCURRENCE}

\section{Site 388}

Poor to moderately well preserved radiolarians were observed in Cores 1, 9, and 10 at Hole 388A. All remaining cores examined were totally barren of siliceous microfossils.

Core 388A-1, Core-Catcher, contains a moderate to well preserved, diverse assemblage of mixed middle to early Miocene and Eocene radiolarians. Since calcareous forminifers and nannoplankton diagnostic of a Pleistocene age were common throughout Core 1 , the radiolarians present in Sample 388A-1, CC were obviously winnowed from submarine outcrops along the continental slope or rise and redeposited in ponded turbidites accumulating between the continental rise hills. The well-preserved nature of the radiolarians in Sample 388A-1, CC indicates they were not transported far by currents and thus the out-crop source was nearby.

Sample 388A-9-5, 102-104 cm, contains only a few fragments of Orosphaerid spines and undiagnostic spumellarians; however, Sample 388-9-6, 119-121 cm, contains a poorly preserved yet more diverse radiolarian assemblage diagnostic of a middle Miocene age. Most radiolarians found in Section 388A-9-6 were fragmented and indicate that they were reworked to some degree. The abundance of Orosphaerid and Collosphaerid radiolarians (tropical to subtropical forms) in Core 9 suggests that a warm climate prevailed at Site 388 during the middle Miocene.

Samples 388A-10-1 and 10, Core-Catcher contain only digitate spines of Orosphaerid radiolarians; consequently no age determination is possible.

\footnotetext{
${ }^{1}$ Present Address: Exxon Production Research Co., P.O. Box 2189. Houston, Texas.
}

\section{Site 390}

Two holes, 390 and 390A, were drilled on the Blake Nose. Hole 390 was cored to a subbottom depth of 206 meters and contains Maestrichtian to Barremian sediments. We found no radiolarian remains in any of the nine cores recovered from this hole. In Hole $390 \mathrm{~A}$, however, we recovered a continuously cored lower Tertiary and Upper Cretaceous section that contains abundant and well-preserved radiolarians within lower and middle Eocene intervals.

Figure 1 illustrates the relative abundances and ranges of the most common radiolarians from Hole 390A. The biostratigraphic zonation employed is from Riedel and Sanfilippo (in press).

The Thyrsocyrtis triacantha Zone is represented at Hole $390 \mathrm{~A}$ in Core 2, Section 1 through Core 4, Section 5 (Figure $2)$. The base of this zone is recognized by the first morphotypic appearance of Eusyringium legena. Species frequently occurring within this interval include $T$. mongolfieri, C. ampulla, L. ocellus gp., P. striata striata, $P$. papalis, $P$. sinuosa, T. triacantha, $L$. biaurita, L. anoectum, T. rhizodon, T. amphora gp., Lych. bellum, T. urceolus, and C. hispida.

The Theocampe mongolfieri and Theocotyle cryptocephala cryptocephala zones are not recognized at Hole 390A.

Core 4 , Section 6 and Core 5, Section 1 are barren of siliceous microfossils.

The Phormocyrtis striata striata Zone occurs in Core 5, Section 2 through Core 6 , Section 5 . The base of this zone is recognized by the first morphotypic occurrence of Theocorys anaclasta.

Core 6 , Section 6 through Core 7 , Section 4 is assigned to the Buryella clinata Zone (Figure 2). The base of this zone is identified by the evolutionary bottom of Buryella clinata (Figure 1).

The core-catcher sample of Core 7 falls within the Bekoma bidartensis Zone of Rieldel and Sanfilippo (in press). This zonal assignment is based upon the dominance of $B$. tetradica relative to $B$. clinata in this sample.

\section{Hole 391A}

Neogene radiolarians are present in varying abundance and preservation in the upper 20 cores. A single sample of

TABLE 1

Location of Leg 44 Holes From Which Radiolarians Were Recovered

\begin{tabular}{lcclc}
\hline \multicolumn{1}{c}{ Hole } & Latitude & Longitude & \multicolumn{1}{c}{ Location } & Water Depth $(\mathrm{m})$ \\
\hline $388 \mathrm{~A}$ & $35^{\circ} 31.33^{\prime} \mathrm{N}$ & $69^{\circ} 23.76^{\prime} \mathrm{W}$ & Continental Rise & 4919 \\
$390,390 \mathrm{~A}$ & $30^{\circ} 08.54^{\prime} \mathrm{N}$ & $76^{\circ} 06.74^{\prime} \mathrm{W}$ & Blake Plateau & 2670 \\
$391 \mathrm{~A}$ & $28^{\circ} 13.70^{\prime} \mathrm{N}$ & $75^{\circ} 36.90^{\prime} \mathrm{W}$ & Blake-Bahama Basin & 4963 \\
\hline
\end{tabular}




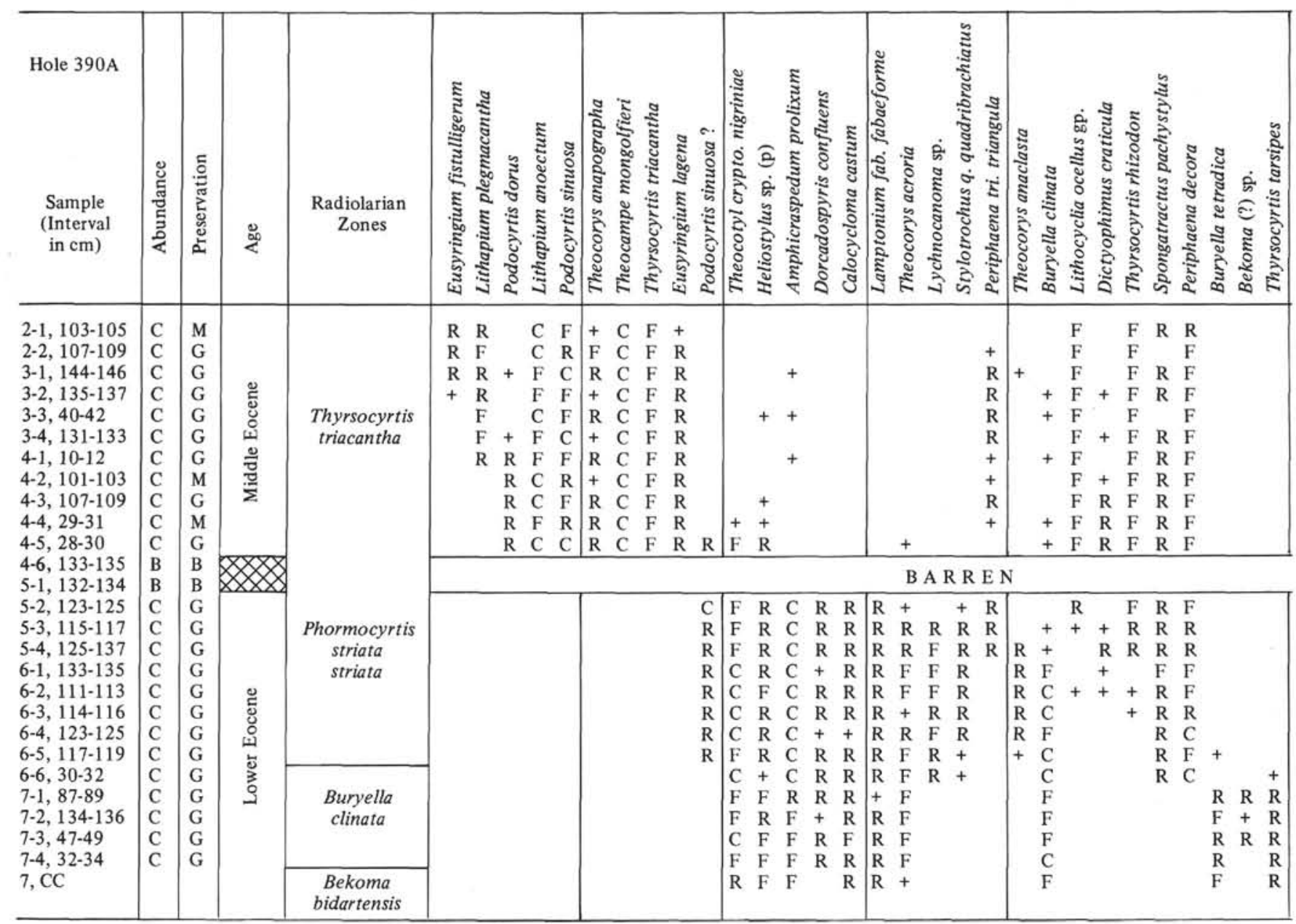

Figure 1. Radiolarians at Hole $390 \mathrm{~A}$.

Pleistocene sediment yielded a diverse assemblage of well-preserved radiolarians in which the most characteristic constituents are: Amphirhopalum ypsilon (three or four chambers before the bifurcation), Euchitonia mulleri, Ommatartus tetrathalamus, Polysolenia murrayana, $P$. spinosa, Tetrapyle octacantha, Heliodiscus asteriscus, Druppatractus aquilonius, Lamprocyclas maritalis, Lithopera bacca, Eucyrtidium tumidulum, E. acuminatum, Anthocyrtidium ophirense, and Dictyophimus crisae. The nature of the assemblage suggests it falls within the Amphirhopalum ypsilon Zone, which dates the sample as lower Pleistocene (Figure 3). The presence of Stichocorys peregrina, $S$. delmontensis, Cyrtocapsella tetrapera, $C$. isopera, Thyrosocyrtis rhizodon, and Theocampe mongolfieri provides evidence that the sample contains reworked Pliocene, Miocene, and Eocene age sediments. Collosphaerids occur in abundance and are well preserved in this sample (Plate 3, Figure 7).

The next few meters of sediment below this sample contain no siliceous microfossils. Siliceous microfossils are present again in sediments from the base of Core 5, Section 6, and, except for one sample $(11-2,20 \mathrm{~cm})$ and one interval for which no samples were available (Cores 14 and 15), they occur continuously throughout Cores 5 through 20 .

Cores $5,6,9,10,11$, and 12 consist of displaced intraclastic carbonate oozes and chalks, the majority of which appear to have been displaced by debris flows and slumping from the Blake Plateau region. Many of the clasts contained within these cores are rich in siliceous microfossils. They were sampled and analyzed in an attempt to date the number of separate depositional events responsible for this large amount of carbonate deposition throughout the Blake-Bahama Basin. Radiolarian age assignments for these cores thus are the ages of the displaced siliceous clasts. Only those sediments from Core 7 and Core 8 , Section 1 represent undisturbed normal pelagic deposition.

The Dorcadospyris alata Zone comprises the interval from the bottom of Core 5 to approximately halfway down Core 7 . Tentatively, the base of this zone is placed between Samples $7-4,70-72 \mathrm{~cm}$, and $7-5,74-76 \mathrm{~cm}$. A short section of the Calocycletta costata Zone is present in Samples 7-5, 74-76 $\mathrm{cm}$ and $8-1,30-40 \mathrm{~cm}$. The rest of Core 8 contains assemblages characteristic of the Cyrtocapsella tetrapera Zone of the lowermost Miocene. Samples examined from Core 9, however, indicate the next two higher zones (Stichocorys delmontensis and $S$. wolfi zones) are present in that core. Cores 10 through 13 again contain assemblages of the Calocycletta costata Zone (Figure 3 ). No Samples were available from Cores 14 and 15 for which there was virtually no recovery. Since the top of Core 16 is placed in the Stichocorys delmontensis Zone and because it appears that 


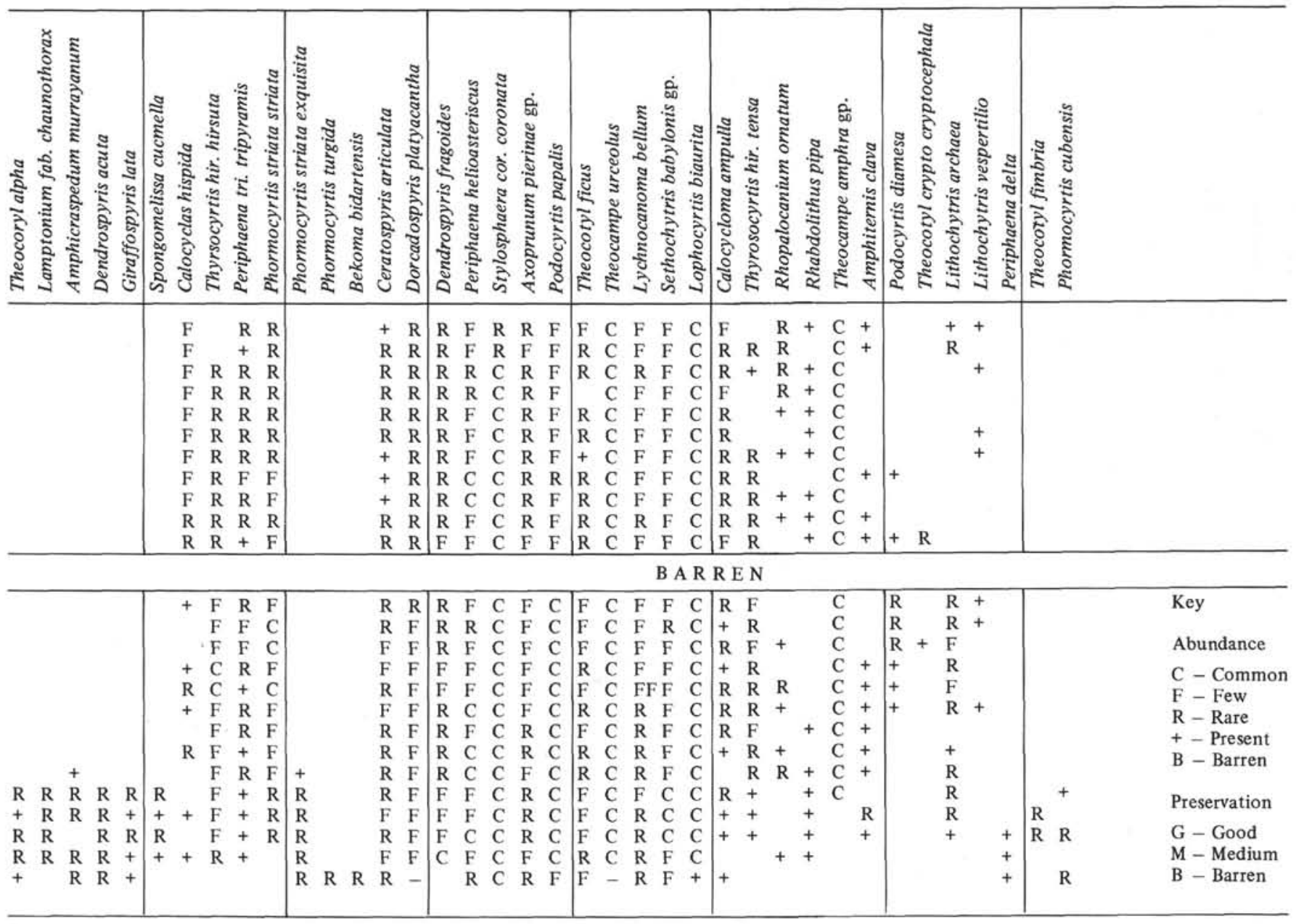

Figure 1. Continued.

the base of the Calocycletta costata Zone lies either at the bottom of Core 13 or just below it, we surmise that the Stichocorys wolffii Zone would be found in unsampled interval of cores 14 and 15 . We could not properly ascertain the base of the Stichocorys delmontensis Zone. Although many radiolarians were found in Cores 17 through 19, they were generally poorly preserved making zone assignments in this interval difficult. A further problem is the presence of small amounts of reworked, predominantly middle Eocene radiolarians throughout most of the Miocene section. Detailed analyses of the radiolarians from this interval indicate that the base of the $S$. delmontense Zone could lie anywhere between Samples 17-3, 84-86 cm and 19-4, 34-37 $\mathrm{cm}$. The base of the Cyrtocapsella tetrapera Zone is tentatively placed between Samples $20-3,84-86 \mathrm{~cm}$ and $20-4,83-85 \mathrm{~cm}$. The remainder of Core 20 is placed within the Lychnocanoma elongata Zone.

The radiolarian biostratigraphy of Hole 391A is especially interesting in the interval represented by Cores 8 and 9 , where several meters of older sediment are found on top of younger sediments. A reasonable explanation for this is that at the time the $C$. costata Zone sediments were being deposited several episodes of large downslope displacements occurred in the Blake-Bahama Basin. The first episode (event) deposited older material of the $S$. delmontense Zone on top of sediments of the $C$. costata Zone. Later events resulted in the deposition of sequentially older material, exposed upslope, on this sediment pile.

\section{LIST OF SPECIES}

The following list provides a bibliography of references to the radiolarian taxa identified in Leg 44 sediments. In most cases the original author is cited along with an additional reference(s) that contains the current concept of the limits of the species as applied to the identification of the radiolarians in Leg 44 sediments.

Amphicraspedum murrayanum Haeckel, 1887, p. 523, pl. 44, fig. 10; Sanfilippo and Riedel, 1973, p. 524, pl. 10; fig. 3-6; pl. 28, fig. 1 (Plate 11, Figure 2).

Amphicraspedum prolixum Sanfilippo and Riedel, 1973, p. 524, pl. 10, fig. 7-11.

Amphipternis clava (Ehrenberg), Foreman, 1973, p. 430, pl. 7, fig. 16, 17; pl. 9, fig. 2.

Amphirhopalum ypsilon Haeckel, 1887, p. 522; Nigrini, 1967, p. 35, pl. 3, fig. 3a-d.

Anthocyrtidium ehrenbergi (Stöhr, 1880), p. 100, pl. 3, fig. 21a, b; Riedel, 1957 , p. 83-87, pl. 2, fig. 1-5 (Plate 1, Figure 1).

Anthocyrtoma sp. Nigrini, 1974, p. 1066, pl. 2c, fig. 1-5 (Plate 8, Figure 9).

Artophormis gracilis Riedel, 1959, p. 300, pl. 2, fig. 12, 13; Riedel and Sanfilippo, 1970, p. 532, pl. 13, fig. 6, 7.

Axoprunum pierinae group (Clark and Campbell), Sanfilippo and Riedel, 1973 , p. 488 , pl. 1 , fig. $6-12$; pl. 23 , fig. 3 .

Bekoma (?) sp. (Plate 10, Figures 1-6).

Bekoma bidartensis Riedel and Sanfilippo, Foreman, 1973, p. 432, pl. 3, fig. 20, 21; pl. 10, fig. 6; Riedel and Sanfilippo, in press, pl. 3, fig. 3 .

Bekoma campechensis Foreman, 1973, p. 432, pl. 3, fig. 24; pl. 10, fig. 1, 2, 4 (Plate 10, Figure 7).

Buryella clinata Foreman, 1973,p. 433,pl. 8, fig. 1-3; pl.9, fig. 19; Riedel and Sanfilippo, in press, pl. 3, fig. 4 (Plate 8, Figures 6, 7). 


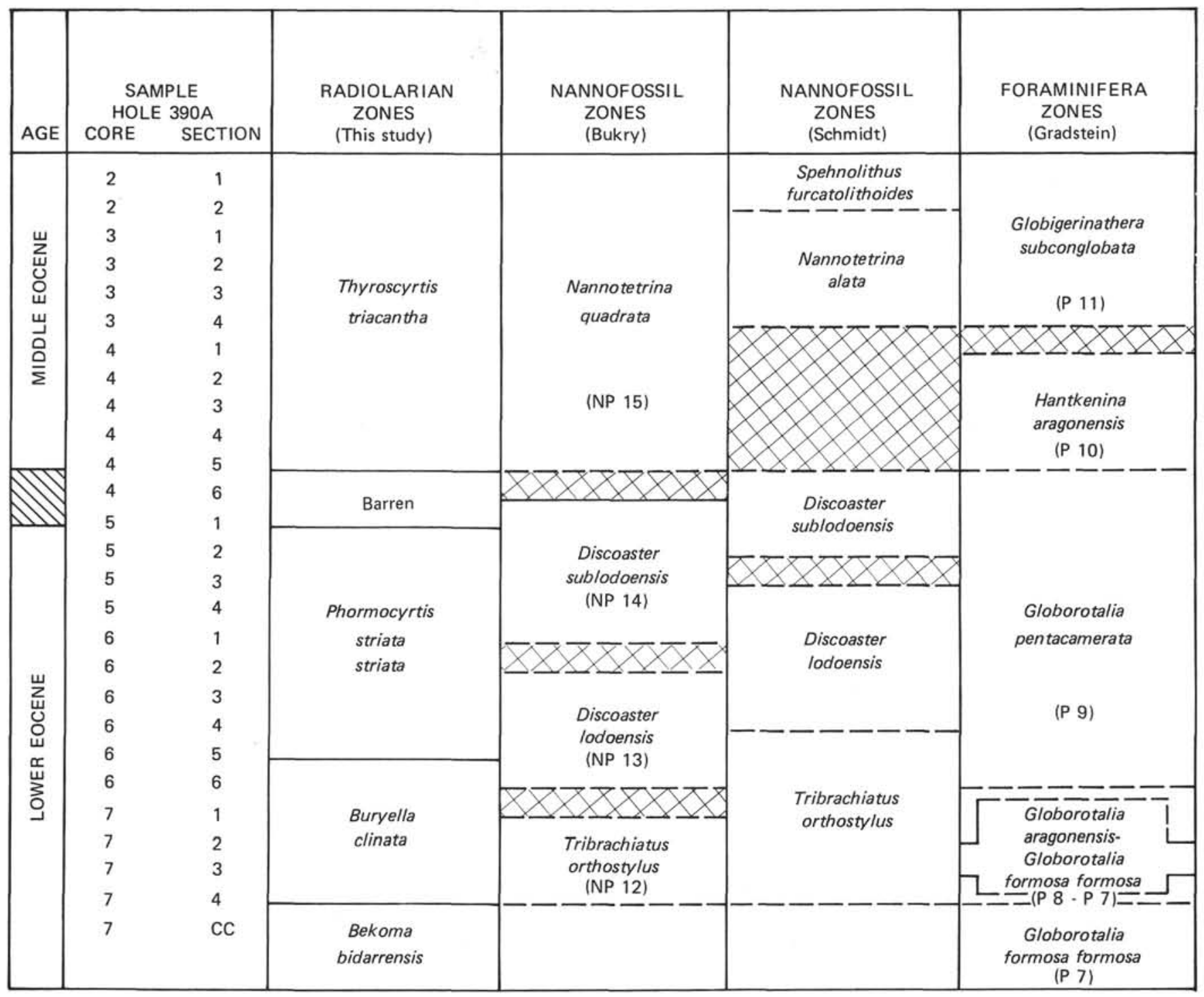

Figure 2. Correlation of planktonic microfossil zones in radiolarianbearing sediments at Hole $390 \mathrm{~A}$.

Buryella tetradica Foreman, 1973, p. 433, pl. 8, fig. 4, 5; pl. 9, fig. 13, 14; Riedel and Sanfilippo, in press, pl. 3, fig. 5.

Calocyclas hispida (Ehrenberg), Foreman, 1973, p. 434, pl. 1, fig. 12-15; Riedel and Sanfilippo, in press, pl. 3, fig. 6.

Calocycletta sp. Remarks: This form appears to be similar to the form illustrated by Ling, 1975, p. 731, pl. 12, fig. 13, 14. However, the forms reported by Ling occur only in the lower Oligocene and are thus considerably older than forms reported here. The presence of Calocycletta sp. in the Miocene section could be caused by admixing of older sediment into younger sediment, for which there is good evidence, or result from the fact that Calocycletta sp. had a longer range in the Blake-Bahama region. (Plate 2, Figure 9).

Calocycletta caepa Moore, 1972, p. 150, pl. 2, fig. 4-7.

Calocycletta costata (Riedel), Riedel and Sanfilippo, 1970, p. 535, pl. 14, fig. 12 ; in press, pl. 3 , fig. 9.

Calocycletta robusta Moore, 1971, p. 743, pl. 10, fig. 5, 6; 1972, p. 48, pl. 1, fig. 6; Riedel and Sanfilippo, in press, pl. 3, fig. 10, 11.

Calocycletta serrata Moore, 1972, p. 148, pl. 2, fig. 1-3; Riedel and Sanfilippo, in press, pl. 3, fig. 12 (Plate 1, Figure 2).

Calocycletta virginis (Haeckel), Moore, 1972, p. 147, pl. 1, fig. 7; Riedel and Sanfilippo, in press, pl. 3, fig. 13, 14.

Calocycloma ampulla (Ehrenberg), Foreman, 1973, p. 434, pl. 1, fig. 1-5; pl. 9 , fig. 20 .
Calocycloma castum (Haeckel), Foreman, 1973, p. 434, pl. 1, fig. 7, 9, 10; Riedel and Sanfilippo, in press, pl. 1, fig. 9; pl. 3, fig. 15 (Plate 5, Figure $11)$.

Cannartus bassanii (Carnevale), Sanfilippo et al., 1973, p. 216, pl. 1, fig. 1-3.

Cannartus laticonus Riedel and Sanfilippo, 1971, pl. 1c, fig. 13, 14; Riedel and Sanfilippo, in press, pl. 4, fig. 1 .

Cannartus mammiferus (Haeckel), Riedel, 1959, p. 291, pl. 1, fig. 4.

Cannartus prismaticus (Haeckel), Riedel and Sanfilippo, 1970, p. 520, pl. 15, fig. 1; 1971, p. 1588, pl. 2c, fig. 11-13.

Cannartus tubarius (Haeckel), Klirg, 1971, pl. 3, fig. 3; Riedel and Sanfilippo, in press, pl. 4, fig. 3.

Cannartus violina Haeckel, 1887, p. 358; Riedel, 1959, p. 290, pl. 1, fig. 3; Moore, 1971, pl. 12, fig. 4; Riedel and Sanfilippo, in press, pl. 4, fig. 4.

Carpocanistrum sp. (p). Riedel and Sanfilipo, 1971, p. 1596, pl. 2f, fig. 5-16; Ling, 1975, p. 730, pl. 12, fig. 3-6.

Carpocanopsis bramlettei Riedel and Sanfilippo, 1971, p. 1597, pl. 2g, fig. 8-14; pl. 8, fig. 7; in press, pl. 4, fig. 6 (Plate 1, Figure 9).

Carpocanopsis cingulata Riedel and Sanfilippo, 1971, p. 1597, pl. 2g, fig. 17-21; pl. 8, fig. 8 ; in press, pl. 4, fig. 7.

Carpocanopsis cristatum (Carnevale) ?, Riedel and Sanfilipo, 1971, p. 1597, pl. 1g, fig. 16; pl. 2g. fig. 1-7. 
Carpocanopsis favosa (Haeckel), Riedel and Sanfilippo, 1971, p. 1597, pl. $2 \mathrm{~g}$, fig. 15, 16; pl. 8, fig. 9-11 (Plate 1, Figure 8).

Centrobotrys petrushevskaya Sanfilippo and Riedel, 1973, p. 532, pl. 36, fig. 12, 13 (Plate 3, Figures 4, 5).

Ceratospyris articulata Ehrenberg, Sanfilippo and Riedel, 1973, p. 526, pl. 15, fig. 1-3; pl. 31, fig. 8, 9; Riedel and Sanfilippo, in press, pl. 4, fig. 9, 10.

Clathrocanium sphaerocephalum Haeckel, 1887, p. 1211, pl. 64, fig. 1; Sanfilippo et al., 1973, pl. 4, fig. 9 (Plate 1, Figures 6, 7).

Clathrocorona atreta Sanfilippo and Riedel, Sanfilippo et al., 1973, p. 219, pl. 4, fig. 5-8.

Clathrocorys sp. Ling, 1975, p. 727, pl. 8, fig. 15, 16.

Cyclampterium (?) leptetrum Sanfilippo and Riedel, 1970, p. 456, pl. 2, fig. 11, 12; Riedel and Sanfilippo, in press, pl. 4, fig. 12, 13.

Cyclampterium (?) pegetrum Sanfilippo and Riedel, 1970, p. 456, pl. 2, fig . 8-10; Riedel and Sanfilippo, 1971, pl. 2d, fig. 13, 14; pl. 3b, fig. 1, 2; in press, pl. 4, fig. 16.

Cyclampterium (?) tanythorax Sanfilippo and Riedel, 1970, p. 457, pl. 2, fig. 13, 14; Riedel and Sanfilippo, 1971, pl. 1e, fig. 8-10; pl. 2d, fig. 7, 8.

Cyrtocapsella sp. Holdsworth, 1975, pl. 2, fig. 17.

Cyrtocapsella cornuta Haeckel, Sanfilippo and Riedel, 1970, p. 453, pl. 1, fig. 19, 20; Sanfilippo et al., 1973, pl. 5, fig. 1, 2; Riedel and Sanfilippo, in press, pl. 4, fig. 17.

Cyrtocapsella elongata (Nakaseko), Sanfilippo and Riedel, 1970, p. 452, pl. 1, fig. 11, 12.

Cyrtocapsella japonica (Nkaseko), Sanfilippo and Riedel, 1970, p. 452, p. 1, fig. 13-15; Sanfilippo et al., 1973, pl. 5, fig. 3.

Cyrtocapsella tetrapera Haeckel, Sanfilippo et al., 1973, pl. 5, fig. 4-6; Riedel and Sanfilippo, in press, pl. 4, fig. 18.

Dendrospyris acuta Goll, Sanfilippo and Riedel, 1973, p. 526, pl. 15, fig. 5; pl. 31, fig. 11.

Dendrospyris bursa Sanfilippo and Riedel, Sanfilippo et al., 1973, p. 217, pl. 2, fig. 9-13 (Plate 3, Figure 2).

Dendrospyris damaecornis (Haeckel), Goll, 1968, p. 1420, pl. 173, fig. $1-4$.

Dendrospyris fragoides Sanfilippo and Riedel, 1973, p. 526, pl. 15, fig. 8-13; pl. 31, fig. 13, 14.

Dendrospyris pododendros (Carnevale), Goll, 1968, p. 1422, pl. 174, fig. $1-4$, test-fig. 8.

Dorcadospyris ateuchus (Ehrenberg), Riedel and Sanfilippo, 1970, pl. 15, fig. $4 ; 1971$, p. 1590, pl. 2d, fig. 6; pl. 3a, fig. 9, 10; in press, pl. 5, fig. 3 .

Dorcadospyris alata (Riedel), Riedel and Sanfilippo, 1970, pl. 14, fig. 5; 1971, pl. 2d, fig. 1; Moore, 1971, pl. 11, fig. 3, 4; Riedel and Sanfilippo, in press, pl. 5, fig. 2.

Dorcadospyris confluens (Ehrenberg), Ehrenberg, 1873, p. 246; Sanfilippo and Riedel, 1973, p. 528, pl. 17, fig. 6-10; pl. 33, fig. 1.

Dorcadospyris dentata (Haeckel), 1887, p. 1037; Riedel, 1957, p. 79, pl. 1, fig. 3; Riedel and Sanfilippo, in press pl. 5, fig. 4.

Dorcadospyris forcipata (Haeckel), Moore, 1971, p. 740, pl. 10, fig. 1, 2.

Dorcadospyris platyacantha (Ehrenberg), Sanfilippo and Riedel, 1973, p. 528 , pl. 17, fig. 11-15; pl. 33, fig. 2 .

Dorcadospyris simplex (Riedel), Riedel and Sanfilippo, 1970, pl. 15, fig. 6.

Dictyophimus craticula Ehrenberg, 1873, p. 223; Sanfilippo and Riedel, 1973, p. 529, pl. 19, fig. 1; pl. 33, fig. 11.

Euchitonia furcata Ehrenberg, Nigrini, 1970, p. 169, pl. 2, fig. 5.

Eucyritidium sp. A Ling, 1975, p. 731, pl. 12, fig. 20.

Eucyrtidium sp. B group (Plate 6, Figure 2).

Eucyritidium acuminatum (Ehrenberg), Nigrini, 1967, p. 81, pl. 8, fig. 3.

Eucyrtidium cienkowskii group Haeckel, 1887, p. 1493; Sanfilippo et al., 1973, p. 221, pl. 5, fig. 7-11.

Eucyrtidium diaphanes Sanfilippo and Riedel, Riedel and Sanfilippo, in press, pl. 5, fig. 5 (Plate 1, Figure 5).

Eucyrtidium punctatum group (Ehrenberg), 1847, p. 43; 1854, pl. 22, fig. 24; Sanfilippo et al., 1973, p. 221, pl. 5, fig. 15, 16.
Eusyringium fistuligerum (Ehrenberg), Foreman, 1973, p. 435, pl. 11, fig 6; Riedel and Sanfilippo, in press, pl. 5, fig. 6, 7 (Plate 5, Figure 1).

Eusyringium lagena (Ehrenberg), Foreman, 1973, p. 435, pl. 11, Fig. 4, 5; Riedel and Sanfilippo, in press, pl. 5, fig. 8 (Plate 5, Figures 2, 3).

Giraffospyris sp. (Plate 4, Figures 1, 2); Remarks: The well-preserved specimens illustrated here are found only rarely: Usually the feet and crown structure have been broken off the specimens and it is difficult to distinguish this species from a number of liriospyris specimens (such as those illustrated by Ling, 1975, pl. 7, fig. 15-20).

Giraffospyris cyrillium Sanfilippo and Riedel, 1973, p. 528, pl. 18, fig. 1-3; pl. 33, fig. 3 (Plate 5, Figure 8).

Giraffospyris lata Goll, Sanfilippo and Riedel, 1973, p. 529, pl. 18, fig. 3-7; pl. 33, fig. 4 (Plate 5, Figure 7).

Gorgospyris sp. (Plate 1, Figure 10).

Gorgospyris perizostra Sanfilippo and Riedel, 1973, p. 213, pl. 3, fig. 4, 5.

Gorgospyris schizopodia Haeckel, 1887, p. 1071, pl. 87, fig. 4; Sanfilippo et al., 1973, p. 218, pl. 3, fig. 6, 7. (Plate 4, Figure 7).

Gorgospyris sp. cf. G. schizopodia (Plate 4, Figures 4, 11). Remarks: Specimens resemble those illustrated by Sanfilippo et al., 1973, pl. 3, fig. 8,9 .

Heliodiscus asteriscus Haeckel, 1887, p. 445, pl. 33, fig. 8; Nigrini, 1967, p. 32 , pl. 3, fig. 1 .

Heliostylus sp. Haeckel, Sanfilippo and Riedel, 1973, p. 522, pl. 8, fig. 1-7; pl. 26, fig. 10-12; pl. 27, fig. 1 (Plate 11, Figure 6).

Histiastrum martinianum Carnevale group, Sanfilippo et al., 1973, p. 217, pl. 2 , fig. 7,8 .

Lamprocyclas sp. group Ling, 1975, p. 731, pl. 13, fig. 2 (Plate 2, Figures $7,8)$.

Lamprocyclas maritalis Haeckel, Nigrini, 1967, p. 74-76, pl. 7, fig. 5.

Lamptonium fabaeforme chaunothorax Riedel and Sanfilippo, 1970, p. 524, pl. 5 , fig. 8,9 ; in press, pl. 5 , fig. 11 .

Lamptonium fabaeforme fabaeforme (Krasheninnikov) Foreman, 1973, p. 436, pl. 6, fig. 6-9; Riedel and Sanfilippo, in press, pl. 5, fig. 13 (Plate 6, Figures 7-10).

Lipmanella sp. group Petrushevskaya and Kozlova, 1972, pl. 37, fig. 2-5.

Liriospyris sp. (Plate 3, Figure 8). Remarks: Specimens of this larger species were a rare but easily recognizable constitutent in a number of samples from Hole 391A. From the illustrations, we suspect that Eucoronis sp. A (Petrushevskaya and Kozlova, 1972, p. 533, pl. 41, fig. 1, 2) is conspecific with this taxon.

Liriospyris parkerae Riedel and Sanfilippo, 1971, p. 1590, pl. 2c, fig. 15; pl. 5, fig. 4; in press, pl. 5, fig. 15 .

Liriospyris stauropora (Haeckel), Goll, 1968, p. 1431, pl. 175, fig. 1-3, 7; Riedel and Sanfilippo, in press, pl. 5, fig. 16.

Lithapium anoectum Riedel and Sanfilippo, 1970, p. 520, pl. 4, fig. 4, 5; in press, pl. 5, fig. 17.

Lithapium plegmacantha Riedel and Sanfilippo, Sanfilippo and Riedel, 1973 , p. 516, pl. 3, figs. 1, 2; pl. 24. fig. 8, 9.

Lithocampe sp. (Plate 7, Figures 8, 9).

Lithocampe subligata group Stöhr, 1880 , p. 102, pl. 4, fig. 1; Petrushevskaya and Kozlova, 1972, p. 546, pl. 25, fig. 7-10 (Plate 2, Figures 1, 2).

Lithochytris archaea Riedel and Sanfilippo, Foreman, 1973, p. 436, pl. 2, fig. 4, 5; Riedel and Sanfilippo, in press, pl. 6, fig. 3 (Plate 5, Figures 5, 6).

Lithochytris vespertilio Ehrenberg, Riedel and Sanfilippo, 1970, p. 528, pl. 9 , fig. 8,9 ; in press, pl. 6 , fig. 4 .

Lithocyclia ocellus group Ehrenberg, Riedel and Sanfilippo, 1970, p. 522, pl. 5, fig. 1, 2; in press, pl. 6, fig. 8 (Plate 11, Figure 1).

Lithomelissa sp. aff. L. mitra Bütschli. Remarks: Similar to form illustrated by Chen, 1975 , p. 458 , pl. 8 , fig. 4, 5 (Plate 1, Figure 11).

Lithopera bacca Ehrenberg, Nigrini, 1967, p. 54, pl. 6, fig. 2; Riedel and Sanfilippo, in press, pl. 6, fig. 9.

Lithopera renzae Sanfilippo and Riedel, 1970, p. 454, pl. 1, fig. 21-23, 27; Riedel and Sanfilippo, in press, pl. 6, fig. 11 (Plate 3, Figure 9).

Lophocyrtis biaurita (Ehrenberg), Riedel and Sanfilippo, in press, pl. 6, fig. 13. 


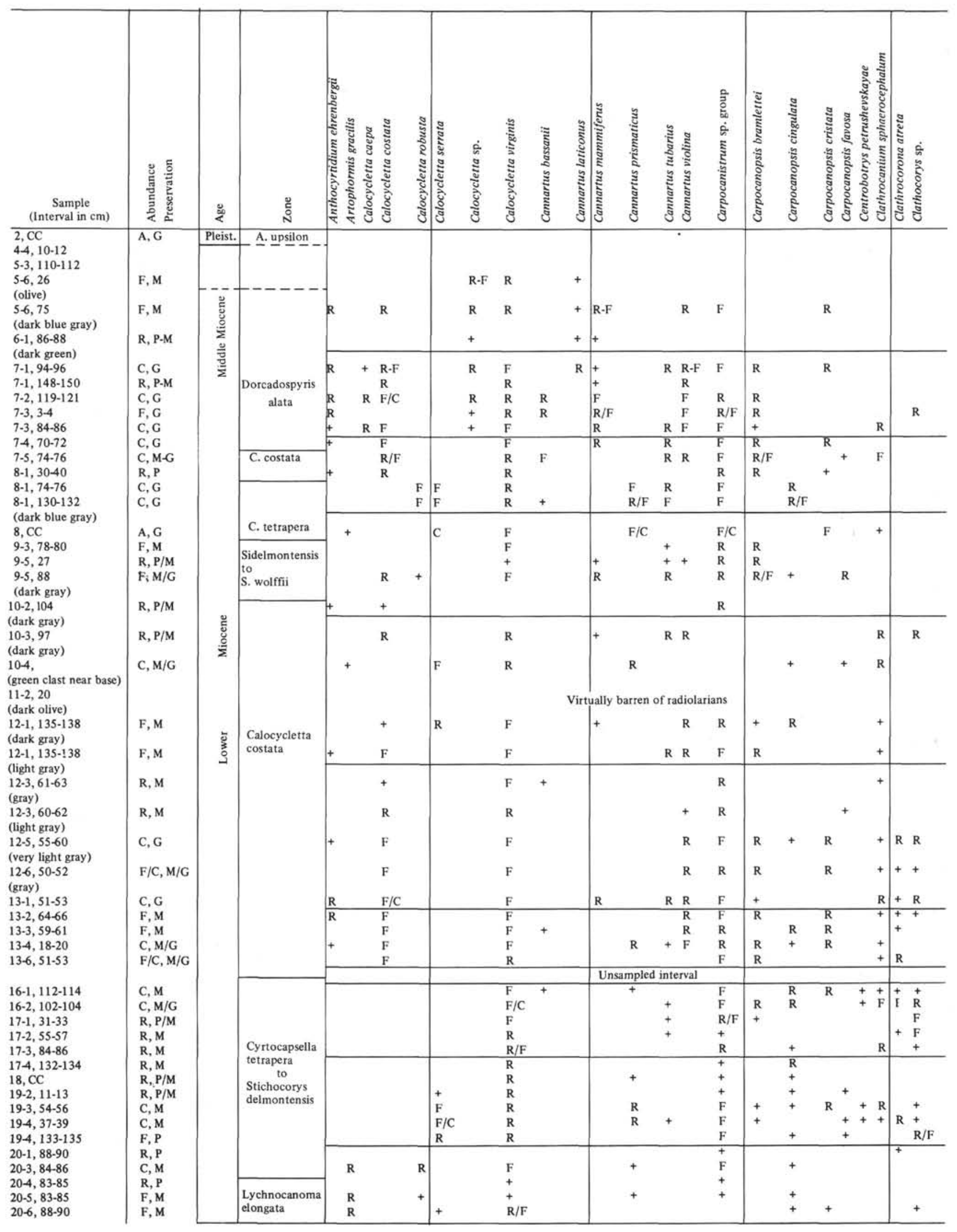

Note: Abundance; A - Abundant; C - Common; F - Few; R - Rare; + - Trace; Preservation; G - Good; M - Moderate; P - Poor.

Figure 3. Radiolarians at Hole $391 \mathrm{~A}$. 


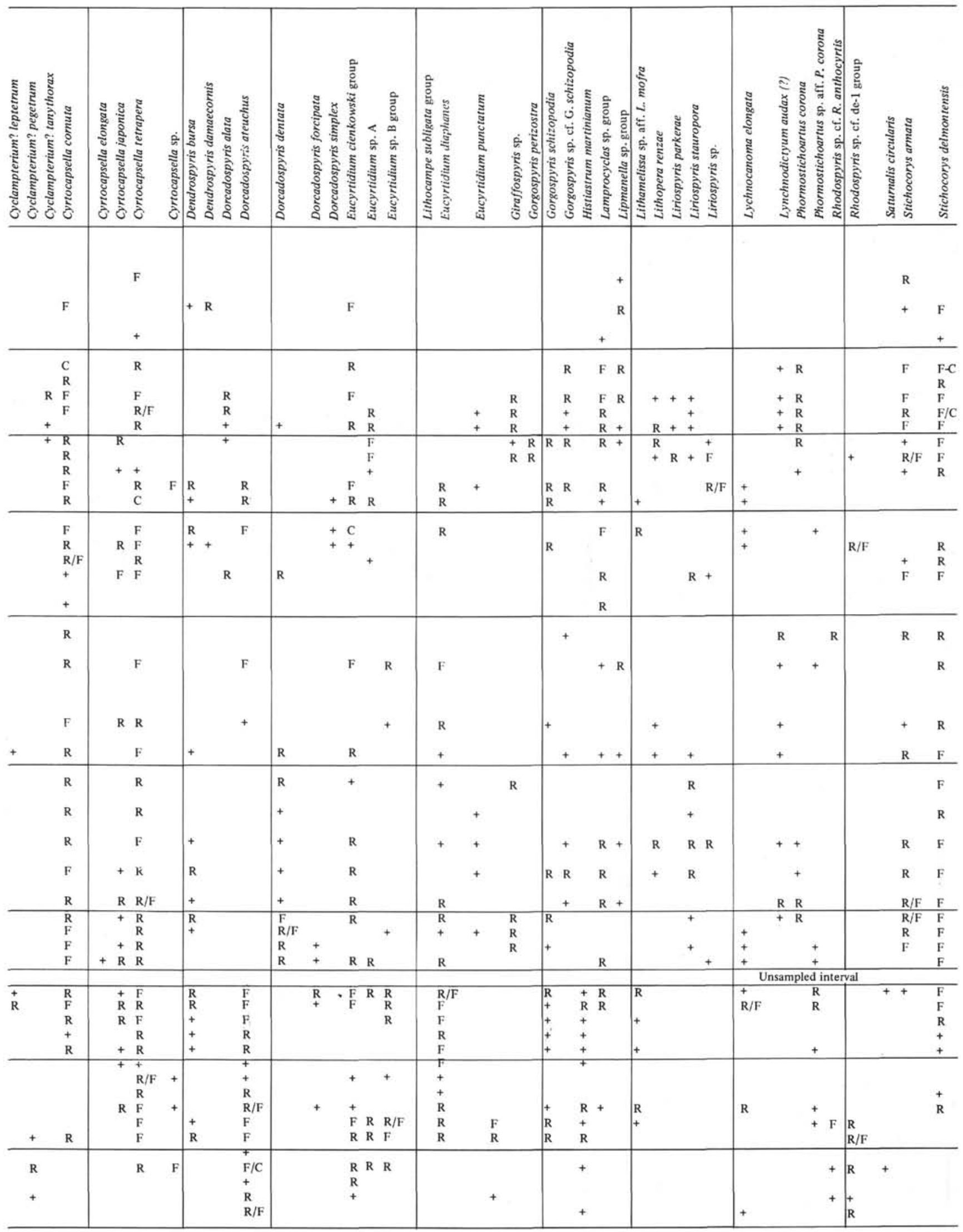

Figure 3. Continued. 


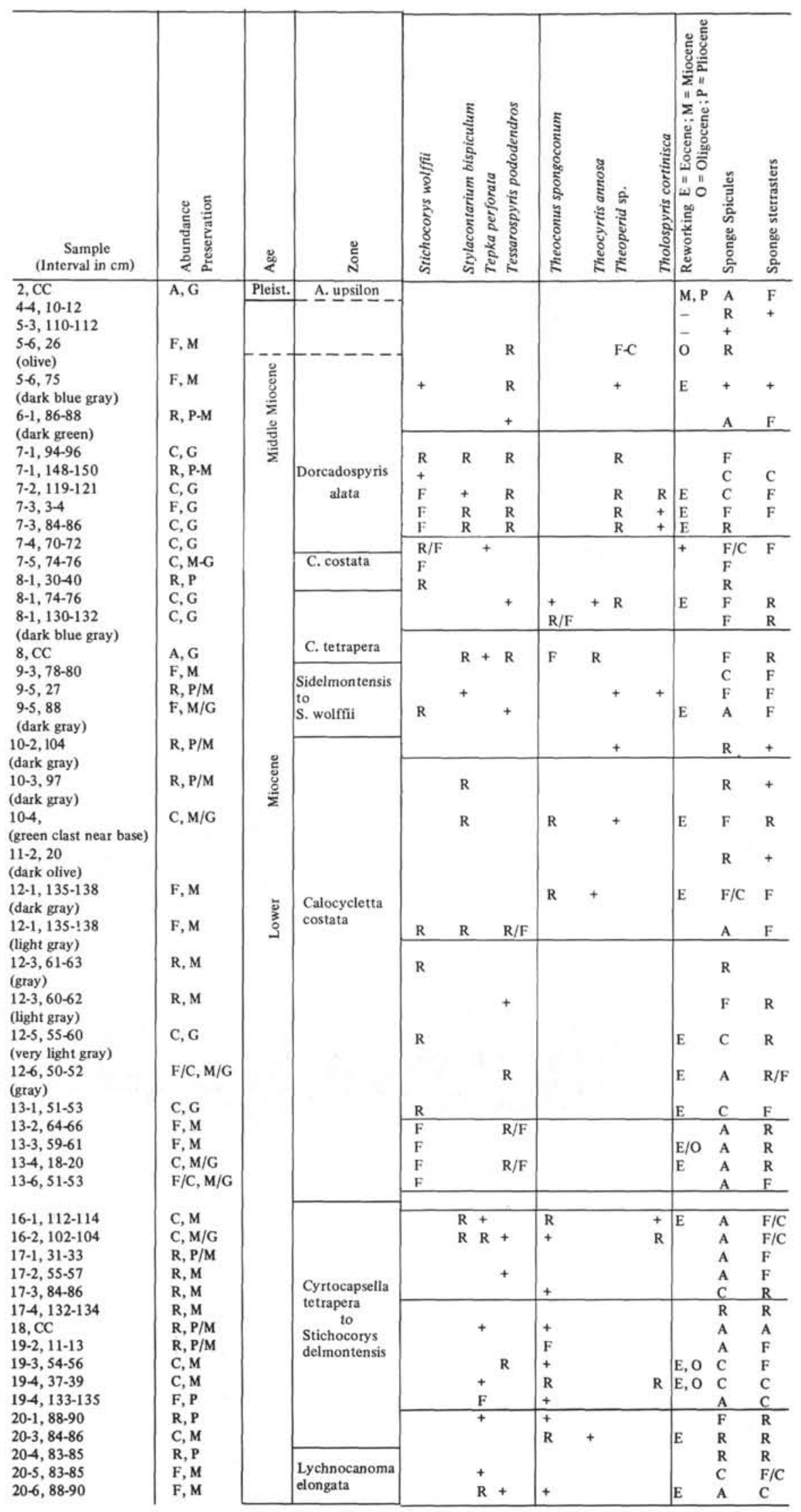

Note: Abundance; A - Abundant; C - Common; F - Few; R - Rare; + - Trace: Preservation; G - Good; M - Moderate; $\mathrm{P}$ - Poor.

Figure 3. Continued. 
Lychnocanoma sp. (Plate 10, Figures 8-10).

Lychnocanoma babylonis group (Clark and Campbell), Foreman, 1973, p. 437 , pl. 2, fig. 1.

Lychnocanoma bellum (Clark and Campbell), Foreman, 1973, p. 437, pl. 1, fig. 17; pl. 11, fig. 9 (Plate 5, Figures 9, 10).

Lychnocanoma elongata (Vinassa), Sanfilippo et al., 1973, p. 221, pl. 5, fig. 19, 20; Riedel and Sanfilippo, in press, pl. 7, fig. 4.

Lychnodictyum audax (?) Riedel, 1953, p. 810, pl. 85, fig. 9; Riedel and Sanfilippo, in press, pl. 7, fig. 5 (Plate 3, Figure 1).

Ommatartus tetrathalamus (Haeckel), Riedel and Sanfilippo, 1971, p. 1588 , pl. 1c, fig. 5-7.

Periphaena decora Ehrenberg, Sanfilippo and Riedel, 1973, pl. 8, fig. 8-10; pl. 27, fig. 2-5 (Plate 11, Figure 5).

Periphaena delta Sanfilippo and Riedel, 1973, p. 523, pl. 8, fig. 11, 12; pl. 27, fig. 6, 7; Riedel and Sanfilippo, in press, pl. 7, fig. 9.

Periphaena heliasteriscus (Clark and Campbell), Sanfilippo and Riedel, 1973, p. 523, pl. 9, fig. 1-6; pl. 27, fig. 8, 9.

Periphaena tripyramis triangula (Sutton), Sanfilippo and Riedel, 1973, p. 523, pl. 9, fig. 10, 11.

Periphaena tripyramis tripyramis (Haeckel), Sanfilippo and Riedel, 1973, p. 523 , pl. 9, fig. 7-9.

Phormostichoartus corona (Haeckel, Riedel and Sanfilippo, 1971, p. 1600, pl. 1i, fig. 13-15; pl. 2 j, fig. $1-5$; in press, pl. 7 , fig. 12 .

Phromostichoartus sp. aff. P. corona (Plate 3, Figure 3).

Podocyrtis diamesa Riedel and Sanfilippo, Sanfilippo and Riedel, 1973, p. 531, pl. 20, fig. 9, 10; Riedel and Sanfilippo, in press, pl. 8, fig. 4.

Podocyrtis dorus Sanfilippo and Riedel, 1973, p. 531, pl. 35, fig. 12-14.

Podocyrtis papalis Ehrenberg, Sanfilippo and Riedel, 1973, pl. 20, fig. $11-14$; pl. 36, fig. $2,3$.

Podocyrtis sinuosa Ehrenberg, Riedel, and Sanfilippo, 1970, p. 534, pl. 11, fig. 3,4 .

Podocyrtis sinuosa (?) Ehrenberg, Sanfilippo and Riedel, 1973, p. 532, pl. 21 , fig. 4,5 .

Phormocyrtis sp. (Plate 8, Figures 1-4).

Phormocyrtis cubensis (Riedel and Sanfilippo), Foreman, 1973, p. 438, pl. 7, fig. 11, 12, 14 (Plate 9, Figures 1(?), 5, 6).

Phormocyrtis turgida (Krasheninnikov), Foreman, 1973, p. 438, pl. 7, fig. 10 ; pl. 12, fig. 6.

Phormocyrtis striata exquisita (Kozlova), Foreman, 1973, p. 438, pl. 7, fig. $1-4,7,8$; pl. 12 , fig. 5 .

Phormocyrtis striata striata Brandt, Foreman, 1973, p. 438, pl. 7, fig. 5, 6, 9; Riedel and Sanfilippo, in press, pl. 7, fig. 11.

Polysolenia murrayana (Haeckel), Nigrini, 1967, pl. 1, fig. 1a-b.

Polysolenia spinosa (Haeckel), group, Nigrini, 1967, p. 14, pl. 1, fig. 1; Ling, 1975, p. 717, pl. 1, fig. 2, 3.

Rhabdolithis pipa Ehrenberg, Sanfilippo and Riedel, 1973, p. 529, pl. 18, fig. 12-16; pl. 33, fig. 9, 10.

Rhodospyris sp. cf. $R$. anthocyrtis Haeckel, Ling, 1975, p. 727, pl. 8, fig. 1, 2 (Plate 4, Figures 9, 10).

Rhodospyris sp. (?) cf. De 1 group Goll, 1968, p. 1417, text-fig. 8; Ling, 1975, p. 727, pl. 8, fig. 3, 4 (Plate 4, Figures 6, 12).

Rhoplocanium ornatum Ehrenberg, Foreman, 1973, p. 439, pl. 2, fig. 8-10; pl. 12, fig. 3.

Saturnalis circularis Haeckel, Nigrini, 1967, p. 25, pl. 1, fig. 9; Ling, 1975 , p. 717 , pl. 2, fig. 2 .

Spongatractus pachystylus (Ehrenberg), Sanfilippo and Riedel, 1973, p. 519 , pl. 2, fig. 4-6; pl. 25, fig. 3 .

Spongodiscus sp. (Plate 11, Figure 4)

Spongodiscus rhabdostylus (Ehrenberg), Sanfilippo and Riedel, 1973, p. 525 , pl. 13, fig. 1-3; pl. 30, fig. 1, 2 (Plate 11, Figure 3).

Spongomelissa cucumella Sanfilippo and Riedel, 1973, p. 530, pl. 19, fig. 6,$7 ;$ pl. 34, fig. 7-10.

Stichocorys wolffii Haeckel, Riedel and Sanfilippo, 1971, pl. 2e, fig. 8, 9; in press, pl. 9, fig. 12.

Stichocorys delmontensis (Campbell and Clark), Sanfilippo and Riedel, 1970, p. 451, pl. 1, fig. 9; Riedel and Sanfilippo, in press, pl. 9, fig. 10.
Stichocorys armata (Haeckel), Sanfilippo et al., 1973, p. 222, pl. 6, fig. 1, 2 (Plate 2, Figure 3).

Stylacontarium acquilonium (Hays), Kling, 1973, p. 634, pl. 1, fig. 17-20; pl. 14 , fig. 1-4.

Stylacontarium sp. aff. S. bisipiculum Kling, 1973, p. 634, pl. 6, fig. 19-23; pl. 14 , fig. 5-8.

Stylosphaera coronata coronata Ehrenberg, Sanfilippo and Riedel, 1973, p. 520, pl. 1, fig. 13-17; pl. 25, fig. 4.

Stylotrochus quadribrachiatus quadribrachiatus Sanfilippo and Riedel, 1973 , p. 526, pl. 14, fig. 1, 2; pl. 31, fig. 1.

Tepka perforata Sanfilippo and Riedel, Sanfilippo et al., 1973, p. 228, pl. 6, fig. 18-20 (Plate 3, Figure 6).

Tetrapyle octacantha Müller, Benson, 1966, p. 245, pl. 15, fig. 3-10; pl. 16 , fig. 1.

Theocampe urceolus group (Haeckel), Foreman, 1973, p. 432, pl. 8, fig. 14-17; pl. 9, fig. 6, 7.

Theocampe mongolfieri (Ehrenberg), Foreman, 1973, p. 432, pl. 9, fig. 6; pl. 9, fig. 17.

Theocorys acroria Foreman, 1973, p. 439, pl. 5, fig. 11-13; pl. 12, fig. 2 (Plate 7, Figures 6, 7).

Theocorys anaclasta Riedel and Sanfilippo, Foreman, 1973, p. 440, pl. 5, fig. 14, 15; Riedel and Sanfilippo, in press, pl. 1, fig. 6-8 (Plate 7, Figures 1-3)

Theocorys anapographa Riedel and Sanfilippo, Foreman, 1973, p. 440, pl. 5, fig. 9, 10; Riedel and Sanfilippo, in press, pl. 9, fig. 15 (Plate 7, Figures 4, 5),

Theocorys spongoconum Kling, 1971, p. 1087, pl. 5, fig. 6; Riedel and Sanfilippo, in press, pl. 9, fig. 16 (Plate 1, Figure 4).

Theocotyle alpha Foreman, 1973, p. 441, pl. 4, fig. 13-15; pl. 12, fig. 16.

Theocotyle cryptocephala cryptocephala (Ehrenberg), Foreman, 1973, p. 440 , pl. 4 , fig. 6,7 ; pl. 12, fig. 18 (Plate 9, Figures 7, 8).

Theocotyle cryptocephala nigrinae Riedel and Sanfilippo, Foreman, 1973, p. 440 , pl. 4, fig. 1, 3-5; pl. 12, fig. 17 (Plate 9, Figures 9-11).

Theocotyle ficus (Ehrenberg), Foreman, 1973, p. 441, pl. 4, fig. 16-20.

Theocotyle fimbria Foreman, 1973, p. 441, pl. 5, fig. 1, 2; pl. 12, fig. 21.

Theocyrtis annosa (Riedel), Riedel and Sanfilippo, 1970, p. 535, pl. 15, fig. 9 ; in press, pl. 10, fig. 3 .

Theoperid sp. (Plate 2, Figure 5).

Tholospyris sp. (Plate 4, Figure 5).

Tholospyris cortinisca (Haeckel), Goll, 1969, p. 325-326, pl. 56, fig. 3, 5 , 6, 8; Sanfilippo et al., 1973, p. 219, pl. 3, fig. 13-16 (Plate 4, Figure 8).

Thyrsocyrtis sp. (Plate 6, Figure 3, 5, 6).

Thyrsocyrtis hirsuta hirsuta (Krasheninnikov), Foreman, 1973, p. 441, pl. 3, fig. 3-8; pl. 12, fig. 15 (Plate 6, Figures 1,2).

Thyrsocyrtis hirsuta tensa Foreman, 1973, p. 442, pl. 3, fig. 13-16; pl. 12, fig. 8 .

Thyrsocyrtis rhizodon Ehrenberg, Foreman, 1973, p. 442, pl. 3, fig. 1, 2.

Thyrsocyrtis tarsipes Foreman, 1973, p. 442, pl. 3, fig. 9; pl. 12, fig. 14 (Plate 6, Figure 4).

Thyrsocyrtis triacantha (Ehrenberg), Foreman, 1973, p. 442, pl. 12, fig. 9-11.

Tricolocampe vitrea Krasheninnikov, 1960, p. 299, pl. 3, fig. 14; Foreman, 1973, p. 438, pl. 7, fig. 13 (Plate 9, Figure 4).

Velicucullus sp(p). Sanfilippo and Riedel, 1973, p. 530, pl. 20, fig. 2-6; pl. 34, fig. 14 (Plate 8, Figure 8).

\section{REFERENCES}

Benson, R.N., 1966. Recent radiolaria from the Gulf of California: Unpublished Ph'd dissertation, University of Minnesota.

Bütschli, O., 1881. Beiträge zur Kenntnis der Radiolarien-skelette, insbesondere der der Cyrtida: Z. Wiss Zool. v. 36, p. 485.

1882. Radiolaria. In Klassen und Ordnungen des Thier-Reichs, H.G. Bronn (Ed.)., v. 1, pt. 1, p. 332.

Chen, P., 1975. Antarctic radiolaria, Leg 28, Deep Sea Drilling Project. In Frakes, L.A., Hayes, D.E., et al., Initial Reports of 
The Deep Sea Drilling Project, Volume 28: Washington (U.S. Government Printing Office), p. 437-513.

Ehrenberg, C.G., 1873. Grössere Felsproben des PolycystinenMergels von Barbados mit weiteren Erläuterungen: Monatsber. Kgl. Preuss. Akad. Wiss. Berlin., Jahre 1873, p. 213.

Foreman, H.P., 1973a. Radiolaria of Leg 10 with systematics and ranges for the families Amphypyndacidae, Artostrobiidae, and Theoperidae.In Worzel, J.L., Bryant, W., et al.,Initial Reports of the Deep Sea Drilling Project, Volume 10: Washington (U.S. Government Printing Office), p. 407-474.

Goll, R.M., 1968. Classification and phylogeny of Cenozoic Trissocyclidae (Radiolaria) in the Pacific and Caribbean Basins. Pt. I.: J. Paleontol., p. 42, p. 1409. , 1969. Classification and phylogeny of Cenozoic Trissocyclidae (Radiolaria) in the Pacific and Caribbean basins. Part II: J. Paleontol., v. 43, p. 322-339.

Haeckel, E., 1887. Report on the Radiolaria collected by H.M.S. Challenger during the years 1873-76: Rept. Voyage Challenger, Zool., v. 18.

Kling, S., 1971. Radiolaria: Leg 6 of the Deep Sea Drilling Project. In Fischer, A.G., Heezen, B.D., et al., Initial Reports of the Deep Sea Drilling Project, v. 6: Washington (U.S. Government Printing Office), p. 1069-1117.

Krasheninnikov, V.A., 1960. Some Radiolarians of the Lower and Middle Eocene of the Western Pre-Caucasus: Min. Geol. i Okhr. Nedr SSSR, Vses, Nauch.-Issled.Geol.Neft.Inst. v. 16, p. 271.

Ling, H.Y., 1975. Radiolaria: Leg 31 of the Deep Sea Drilling Project. In Karig, D.E., Ingle, J.C., Jr., et al., Initial Reports of the Deep Sea Drilling Project, v. 31: Washington (U.S. Government Printing Office), p. 703-761.

Moore, T.C., 1971. Radiolaria. In Tracey, J.I., Jr., Sutton, G.H., et al., Initial Reports of the Deep Sea Drilling Project, v. 8: Washington (U.S. Government Printing Office), p. 727-775. , 1972. Mid-Tertiary evolution of the radiolarian genus Calocycletta: Micropaleontology, v. 18, p. 244-252.

Nigrini, C.A., 1967. Radiolaria in pelagic sediments from the Indian and Atlantic oceans: Scripps Inst.Oceanogr. Bull., v. 11, p. $1-106$.
1971. Radiolarian assemblages in the North Pacific and their application to a study of Quaternary sediments in Core V-20-130. In Hays, J.D. (Ed.), Geological Investigations of the North Pacific. Geol. Soc. Am. Mem. 126, p. 139-183.

Petrushevskaya, M.G. and Kozlova, G.E., 1972. Radiolaria: Leg 14, Deep Sea Drilling Project. In Hayes, D.E., Pimm, A.C., et al., Initial Reports of the Deep Sea Drilling Project, v. 14: Washington (U.S. Government Printing Office), p. 495-648.

Riedel, W.R., 1953. Mesozoic and Late Tertiary Radiolaria of Rotti: J. Paleontol, p. 27, p. 805-813.

, 1957. Radiolaria: a preliminary stratigraphy: Rept. Swed. Deep-Sea Exped., v. 6, p. 61-96.

1959. Oligocene and lower Miocene Radiolaria in tropical Pacific sediments: Micropaleontology, v. 5, 285-302.

Riedel, W.R. and Sanfilippo, A., 1970. Radiolaria, Leg 4, Deep Sea Drilling Project. In Bader, R.G., Gerard, R.D., et al., Initial Reports of the Deep Sea Drilling Project, v. 4: Washington (U.S. Government Printing Office), p. 503-575.

, 1971. Cenozoic Radiolaria from the western tropical Pacific, Leg 7. In Winterer, E.L., Riedel, W.R., et al., Initial Reports of the Deep Sea Drilling Project, v. 7: Washington (U.S. Government Printing Office), p. 1529-1672.

, (in press). Stratigraphy and evolution of tropical Cenozoic radiolarians: Plankton and Sediments Symposium, fourth Planktonic Conference, Kiel.

Sanfilippo, A. and Riedel, W.R., 1970. Post-Eocene 'closed' theoperid radiolarians: Micropaleontology, v. 16, p. 446-462. , 1973. Cenozoic Radiolaria (exclusive of theoperids, artostrobiids and amphypyndacids) from the Gulf of Mexico, Deep Sea Drilling Project, Leg 10.In Worzel, J.L. Bryant, W., et al., Initial Reports of the Deep Sea Drilling Project, v. 10: Washington (U.S. Government Printing Office), p. 475-611.

Sanfilippo, A., Burckle, L.H., Martini, E., and Riedel, W.R., 1973. Radiolarians, diatoms, silicoflagellates and calcareous nannofossils in the Mediterranean Neogene: Micropaleontology, v. 19, p. 205-234.

Stöhr, E., 1880. Die Radiolarienfauna der Tripoli von Grotte Provinz Girgenti in Sicilien: Palaeontographica., v. 26, (Ser. 3, v. 2), p. 71-124. 


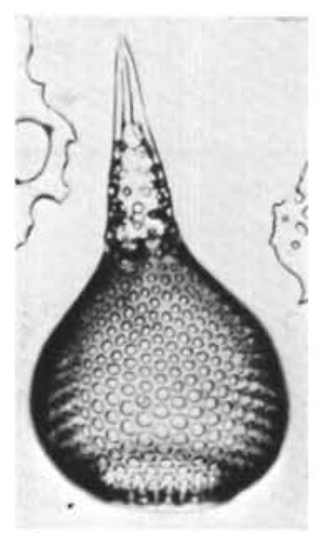

1

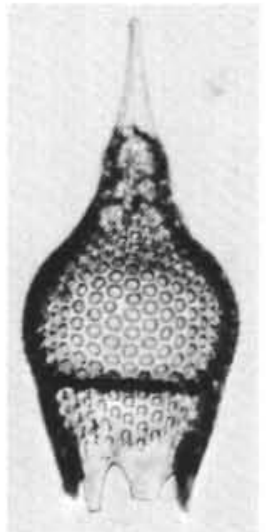

2

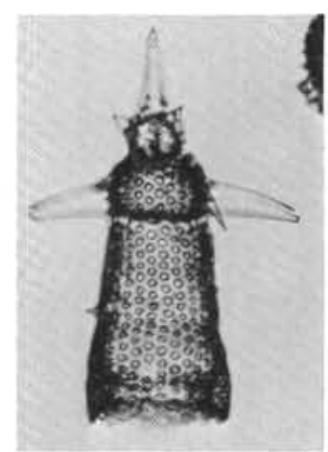

3

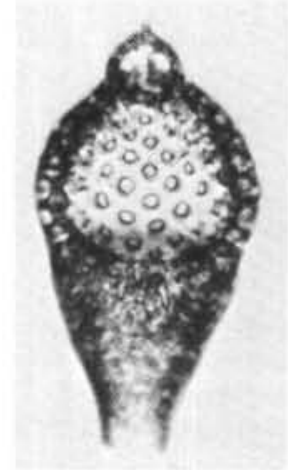

4

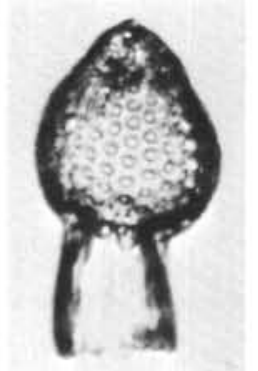

8

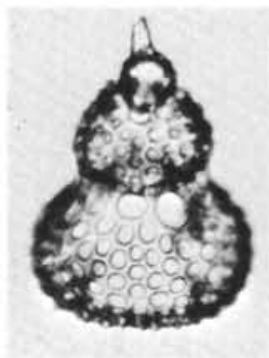

5

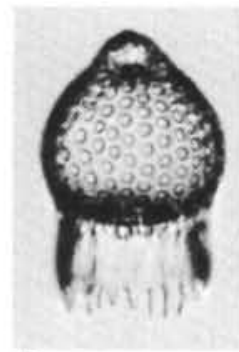

9

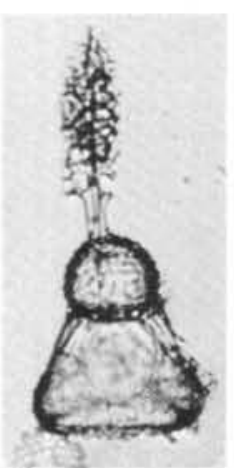

6

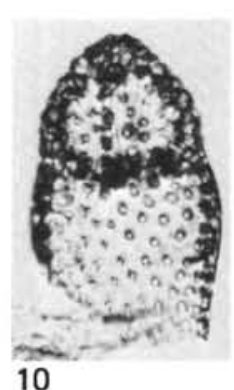

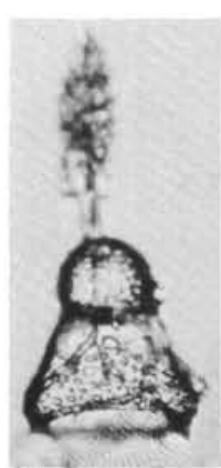

7

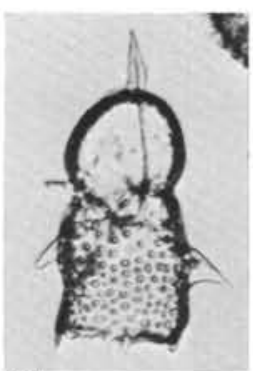

11

PLATE 1

Figure 1 Anthocyrtidium ehrenbergi. Sảmple Figure 6 $391 \mathrm{~A}-7-2,119-121 \mathrm{~cm} ; \times 250$.

Figure 2 Calocycletta serrata. Sample 391A-8-1, 130-132 cm; × 200 .

Figure 3 Theoperid gen. et $\mathrm{sp}$. indet. Sample $391 \mathrm{~A}-7-1,94-96 \mathrm{~cm} ; \times 220$.

Figure 4 Theocorys spongoconum. Sample 391A-8-1, 130-132 cm; $\times 210$.

Figure 5 Eucyrtidium diaphanes. Sample 391A$10-4$, green clast near base of section; $\times$ 290.
Clathrocanium sphaerocephalum. Sample $391 \mathrm{~A}-7-2,119-121 \mathrm{~cm} ; \times 300$.

Figure 7 C. sphaerocephalum. Sample 391A-7-2, $119-121 \mathrm{~cm} ; \times 270$.

Figure 8 Carpocanopsis favosa. Sample 391A19-4, 37-39 cm; $\times 270$.

Figure 9 Carpocanopsis bramlettei. Sample 391A-7-1, 94-96 cm; $\times 240$.

Figure $10 \quad$ Gorgospyris sp. Sample 391A-7-5, 74-76 $\mathrm{cm} ; \times 260$.

Figure $11 \quad$ Lithomelissa sp. cf. L. mitra. Sample 391A-12-5, 55-57 cm; $\times 300$. 


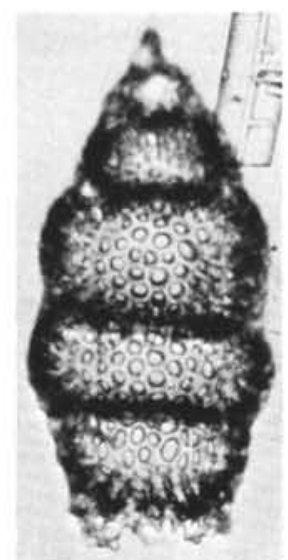

1
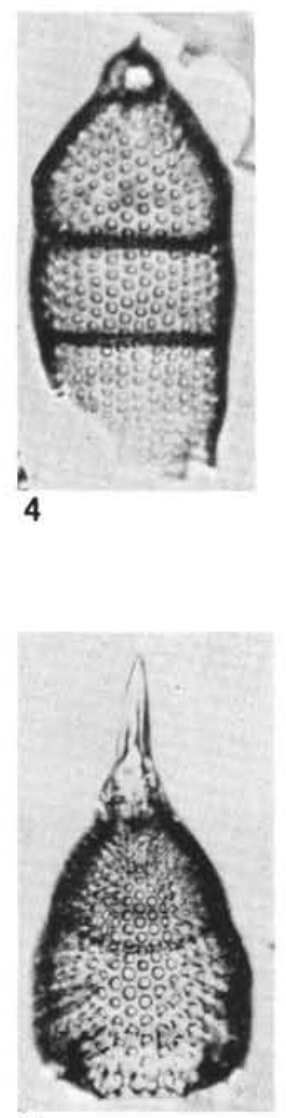

7

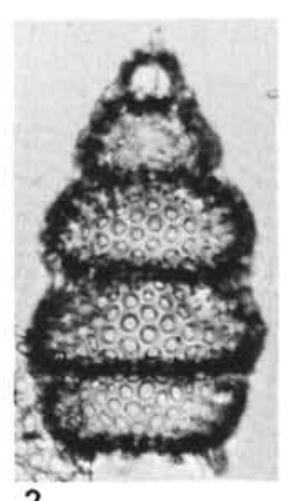

2
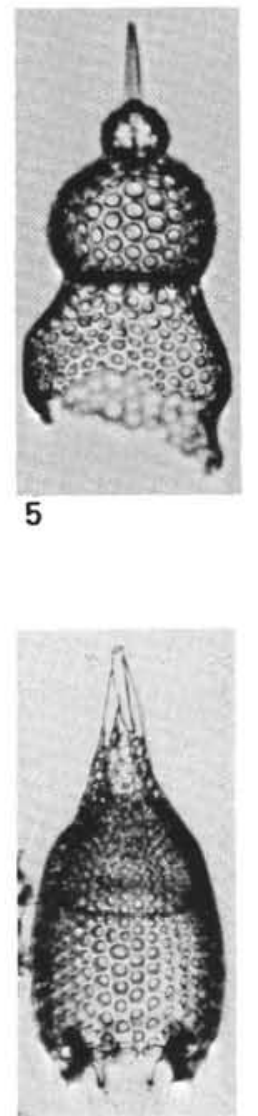

8

PLATE 2

Figures 1,2 Lithocampe subligata group. Sample 391A-20-3, 84-86 cm; × 260.

Figure 3

Stichocorys armata. Sample 391A-7-4, 94-96 cm; $\times 270$.

Figure 4 Eucyrtidium punctatum group. Sample $391 \mathrm{~A}-19-4,37-39 \mathrm{~cm} ; \times 240$.

Figure 5 Theoperid gen. et sp. indet. Sample $391 \mathrm{~A}-5-6,26-28 \mathrm{~cm} ; \times 320$.

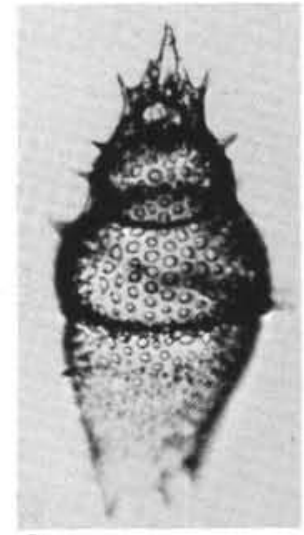

3
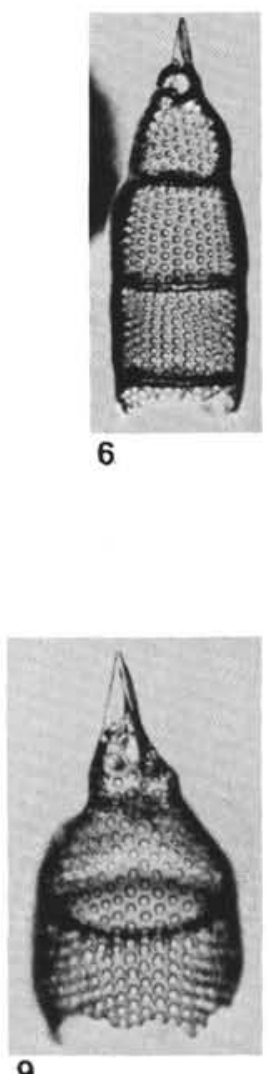

9

Theoperid gen. et sp. indet. Sample $391 \mathrm{~A}-10-4$, green clast near base of section; $\times 230$.

Figure 7

Figure 8

Figure 9
Lamprocyclas sp. Sample 391A-7-4, 94-96 cm; $\times 250$.

Lamprocyclas sp. Sample 391A-8, CC; $\times$ 230.

Calocycletta sp. Sample 391A-7-1, 94-94 $\mathrm{cm} ; \times 260$. 

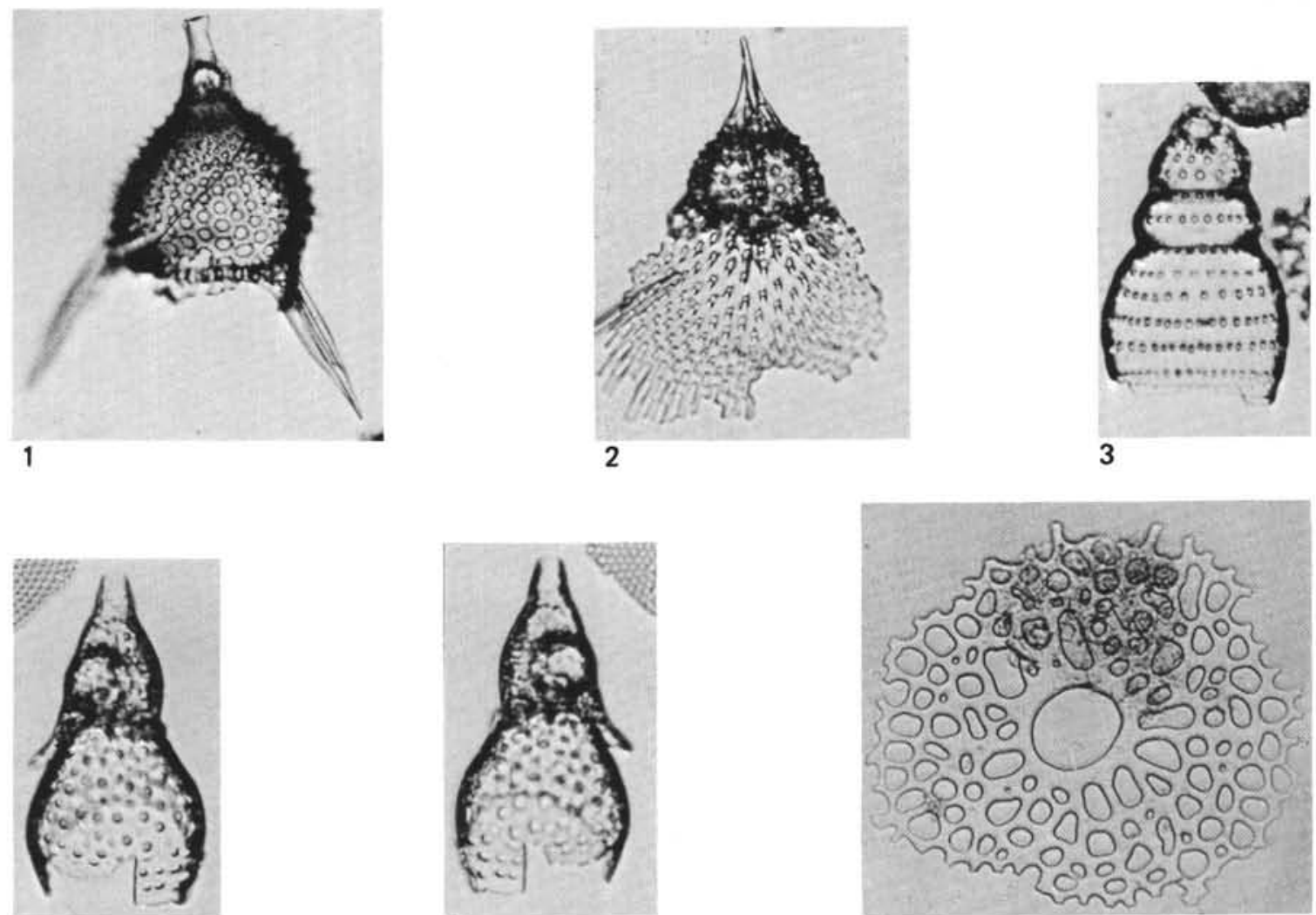

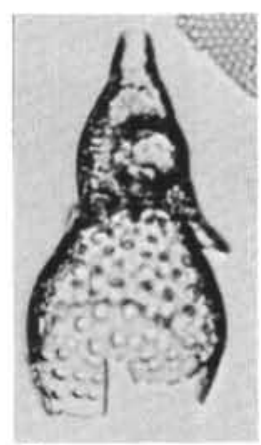

5

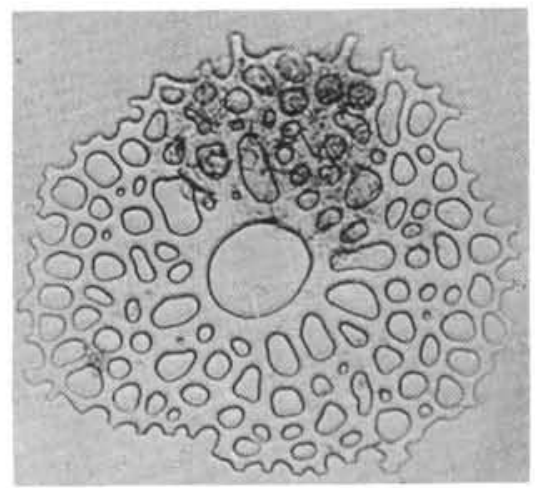

6

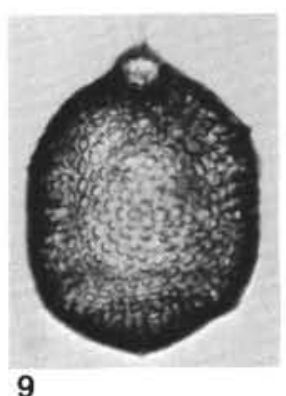

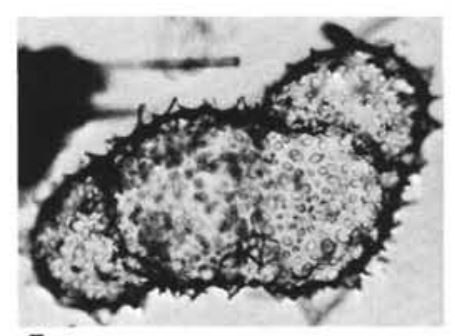

7
8

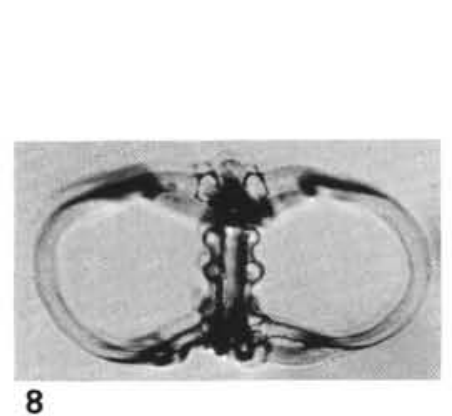

PLATE 3
Figure 1

Lychnodictyum audax (?). Sample 391A-7-1, 94-96 cm; $\times 200$.

Figure 2

Dendrospyris bursa. Sample 391A-13-3, $59-61 \mathrm{~cm} ; \times 270$.

Figure 3

Phormostichoartus sp. cf. P. corona. Sample 391A-8, CC; $\times 290$.

Figures 4,5 Centobotrys petrushevskayae. Sample $391 \mathrm{~A}-19-4,37-39 \mathrm{~cm} ; \times 280$.
Figure 6

Figure 7

Figure 8

Figure 9
Tepka perforata. Sample 391A-20-1, $88-89 \mathrm{~cm} ; \times 230$.

Collosphaerid colony. Sample 391A-2, CC; $\times 150$.

Liriospyris sp. Sample 391A-7-3, 84-86 $\mathrm{cm} ; \times 300$.

Lithopera renzae. Sample 391A-7-2, $119-121 \mathrm{~cm} ; \times 220$. 


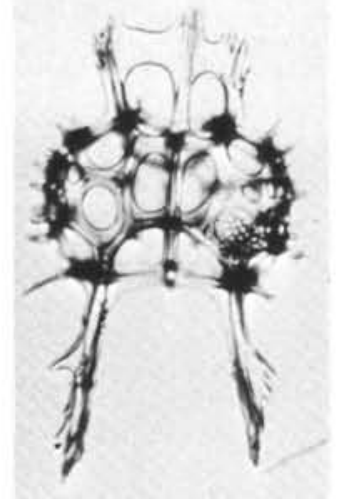

1

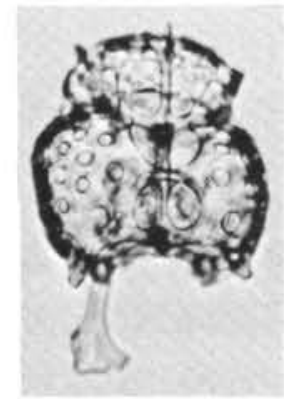

5

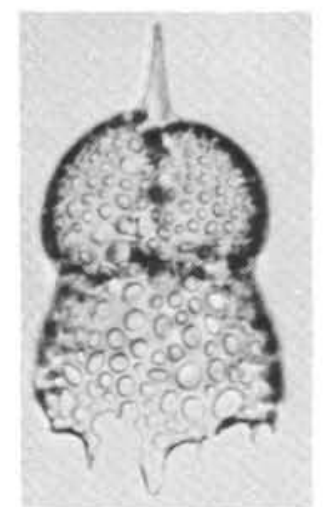

9

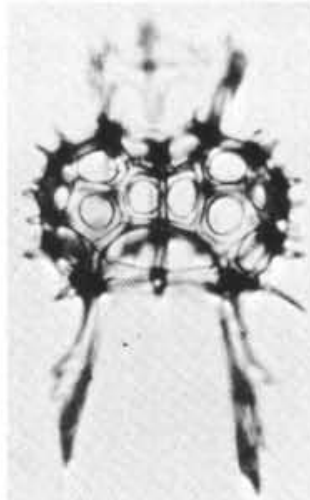

2
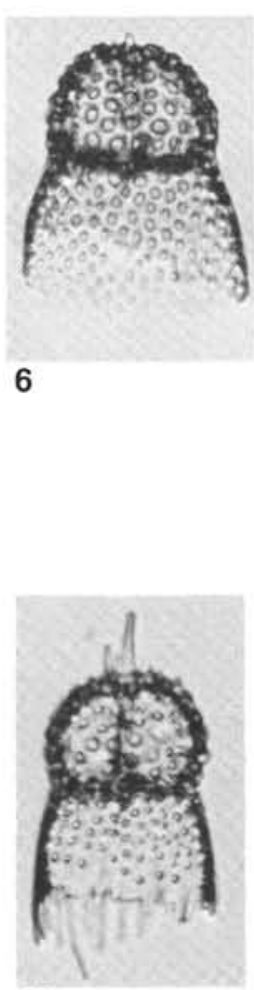

10

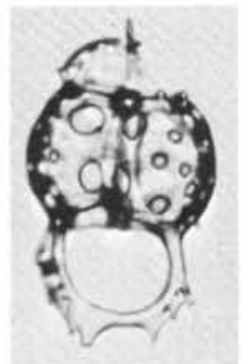

3

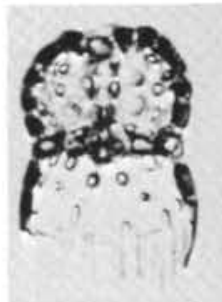

4

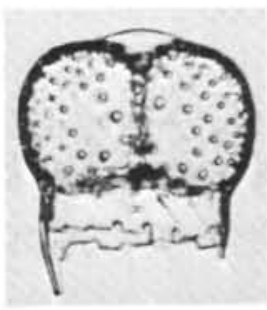

7

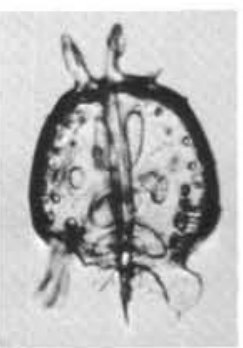

8

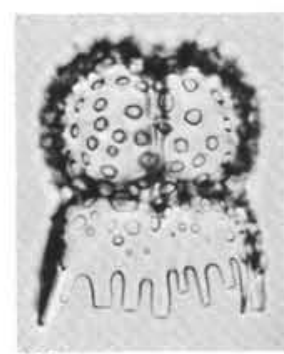

11

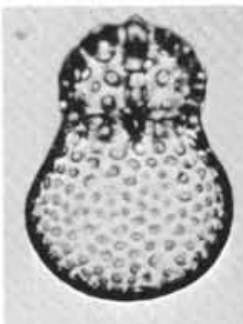

12

PLATE 4

Figures 1,2 Giraffospyris sp. Sample 391A-7-2, 119$121 \mathrm{~cm} ; \times 280$.

Figure 3

Tholospyris sp. Sample 391A-7-2, 119$121 \mathrm{~cm} ; \times 240$.

Figure $4 \quad$ Gorgospyris sp. cf. G. schizopodia. Sample $391 \mathrm{~A}-8-1,130-132 \mathrm{~cm} ; \times 220$.

Figure 5 Tholospyris (?) sp. Sample 391A-9-5, $27-29 \mathrm{~cm} ; \times 320$.

Figure $6 \quad$ Rhodospyris (?) sp. De 1 group. Sample $391 \mathrm{~A}-19-4,37-39 \mathrm{~cm} ; \times 210$.

Figure 7 Gorgospyris schizopodia. Sample $391 \mathrm{~A}-7-5,74-76 \mathrm{~cm} ; \times 300$.
Figure 8

Figure 9

Figure 10

Figure 11

Figure 12
Tholospyris cortinisca. Sample 391A-7-3, $34-36 \mathrm{~cm} ; \times 280$.

Rhodospyris sp. cf. R. anthocyrtis. Sample $391 \mathrm{~A}-19-4,37-39 \mathrm{~cm} ; \times 300$.

Rhodospyris sp. cf. R. anthocyrtis. Sample $391 \mathrm{~A}-19-4,37-39 \mathrm{~cm} ; \times 220$.

Gorgospyris sp. cf. G. schizopodia. Sample 391A-7-1, 94-94 cm; $\times 200$.

Rhodospyris (?) sp. De 1 group. Sample 391A-10-4, green clast near the bottom of section; $\times 210$. 


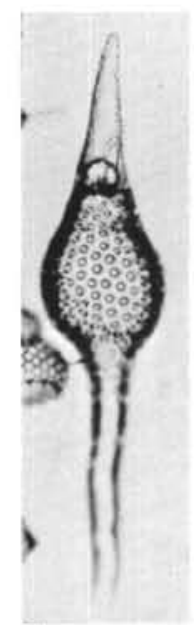

1

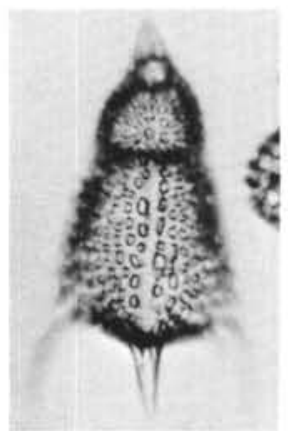

5

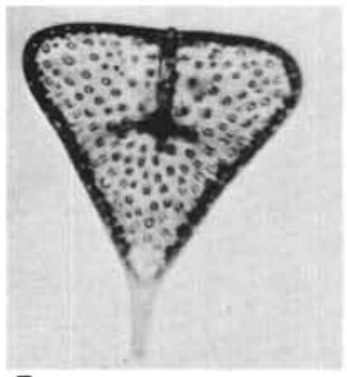

7

8

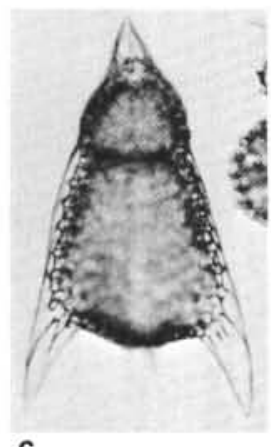

6
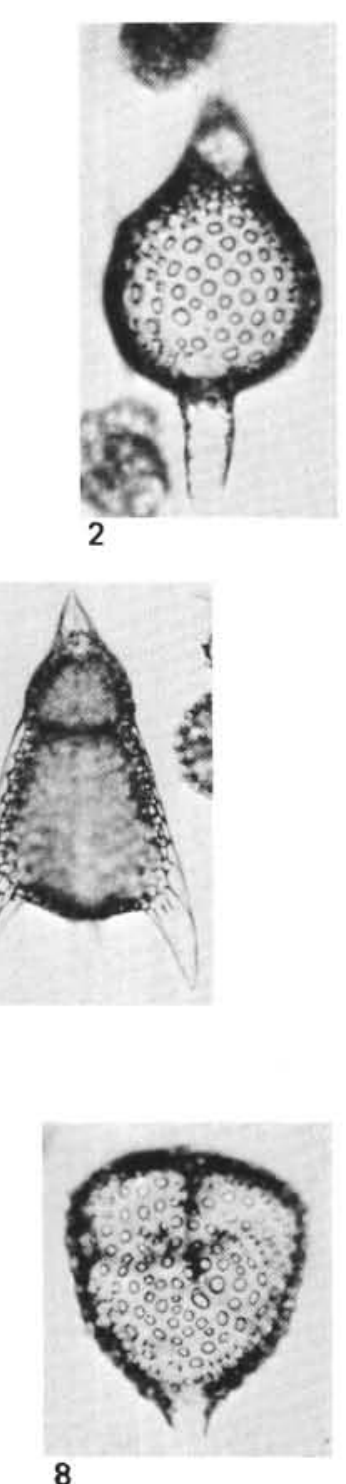

9

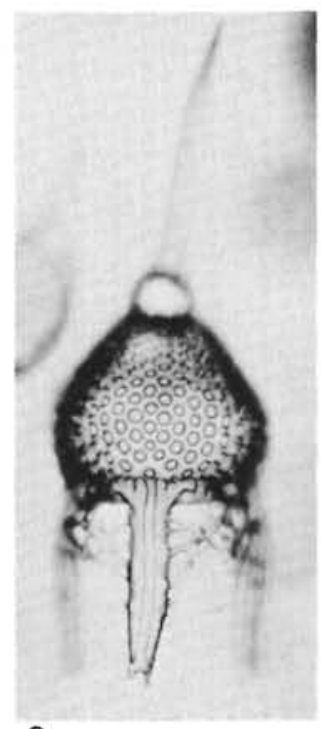

9

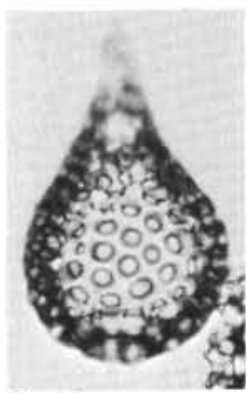

3

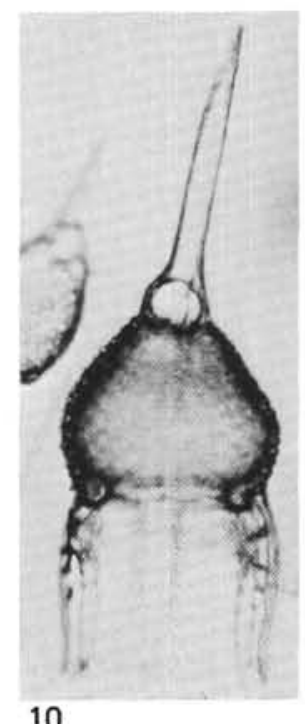

11

4
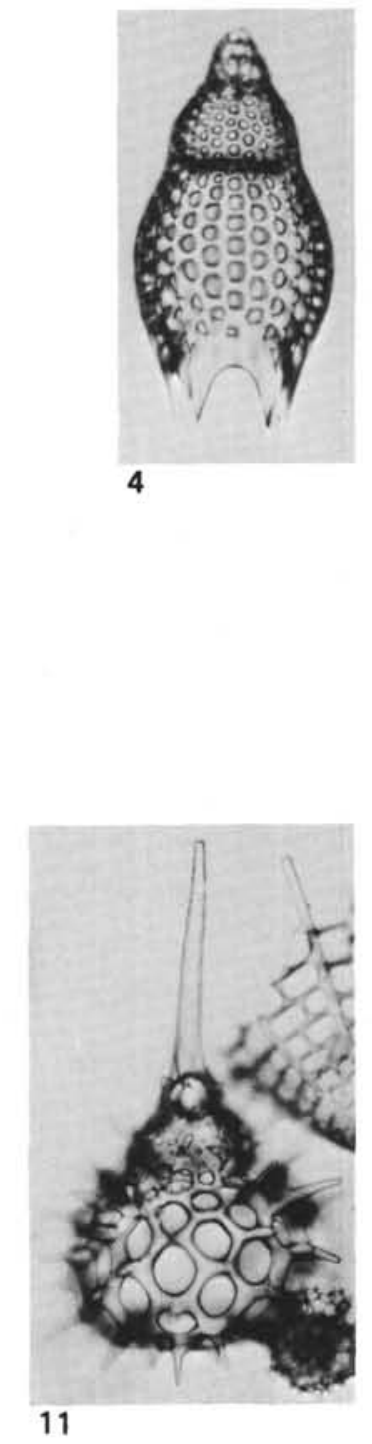

PLATE 5

Figure 1 Eusyringium fistuligerum. Sample Figure 6 390A-2-2, 107-109 cm; $\times 170$.

Figure 2 Eusyringium lagena (with tubule). Sample Figure 7 390 A-3-1, 144-146 cm; $\times 270$. $\begin{array}{ll}\text { Figure } 3 & \begin{array}{l}\text { Eusyringium lagena. Sample 390A-4-2, } \\ 101-103 \mathrm{~cm} ; \times 270 .\end{array}\end{array}$

Figure 4 Podocyrtis sinuosa (?). Sample 390A-3-3, Figures 9,10 99-101 cm; $\times 160$.

Figure $5 \quad$ Lithochytris archaea. Sample 390A-6-2, Figure 11 $111-113 \mathrm{~cm} ; \times 160$.
Lithochytris archaea. Sample 390A-6-2, $111-113 \mathrm{~cm} ; \times 180$.

Giraffospyris lata. Sample 390A-7-2, 49-51 cm; $\times 200$.

Giraffospyris cyrillium. Sample 390A-54, 125-127 cm; $\times 260$.

Lychnocanoma bellum. Sample 390A-45, 28-30 cm; $\times 190$.

Calocycloma castum. Sample 390A-6-6, $30-32 \mathrm{~cm} ; \times 150$. 

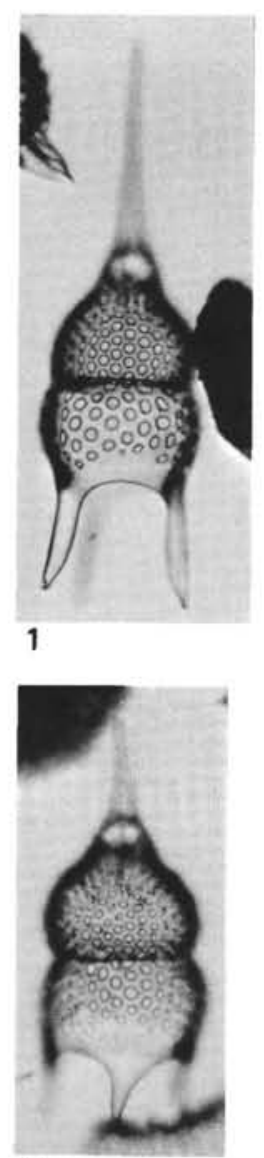

5

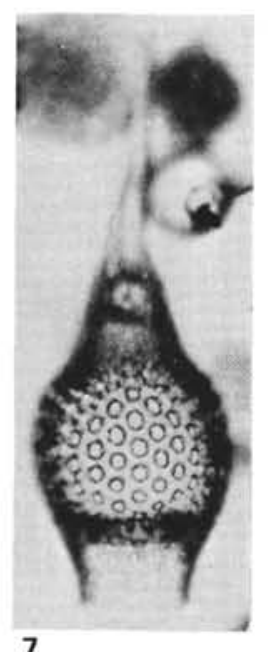

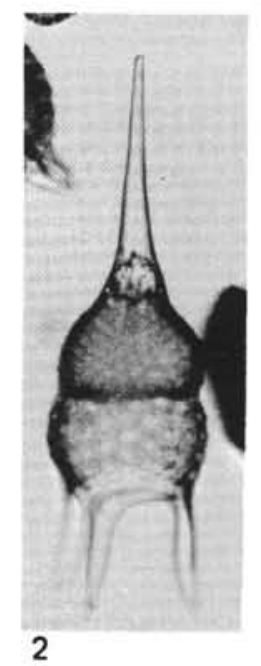

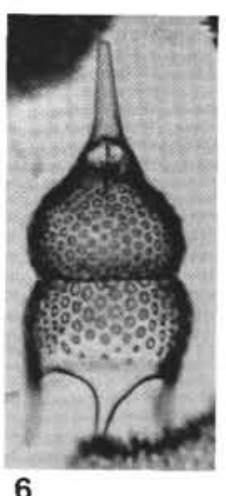

6

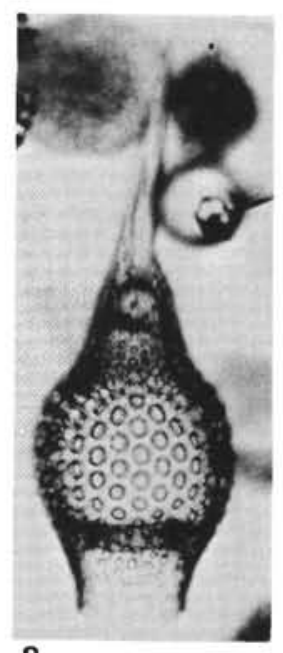

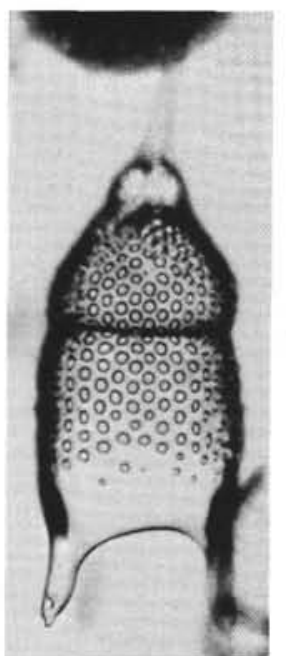

3
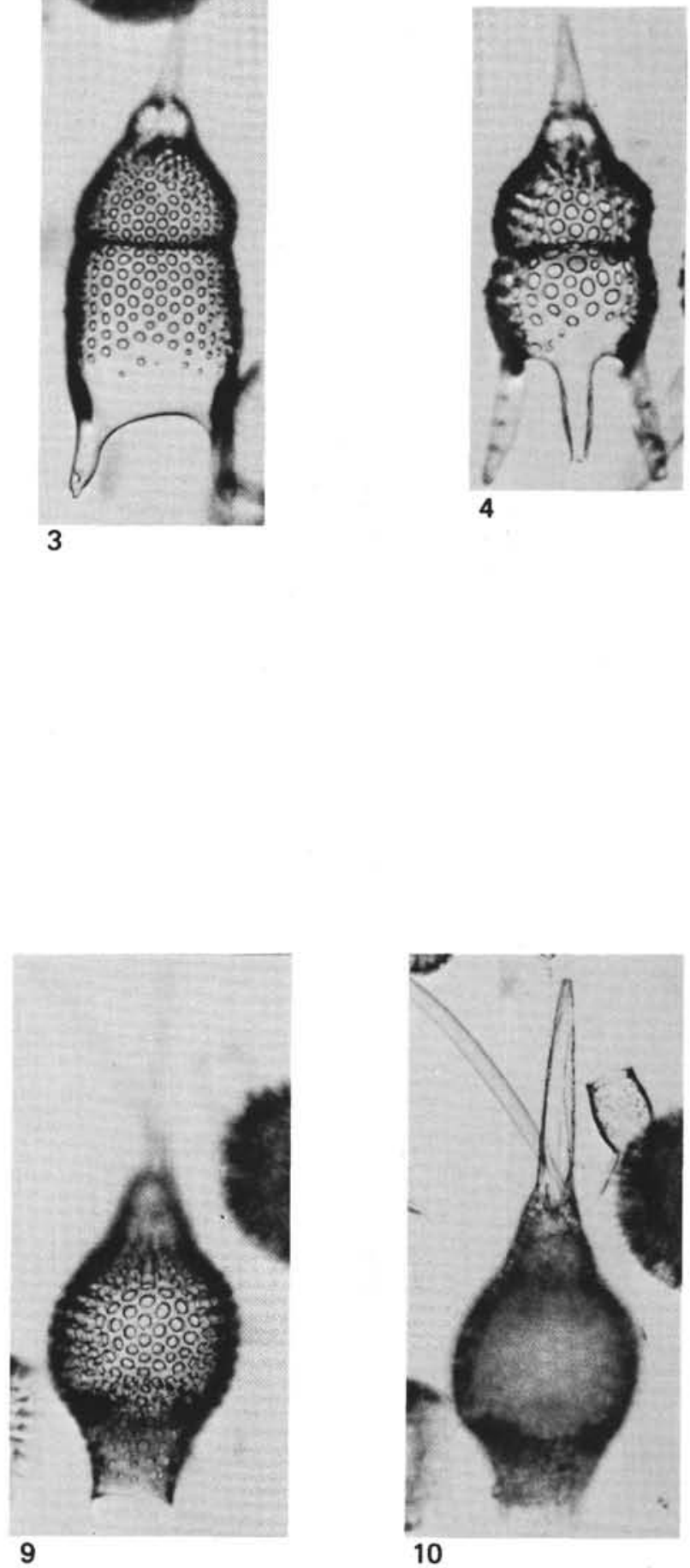

PLATE 6

Figures 1,2 Thyrsocyrtis hirsuta hirsuta. Sample 390A-6-4, 123-125 cm; × 150.

Figure 3

Thyrsocyrtis sp. Sample 390A-5-4, 125 $127 \mathrm{~cm} ; \times 150$.

Figure 4 Thyrsocyrtis tarsipes. Sample 390A-7-2, $49-51 \mathrm{~cm} ; \times 200$. (Pores in feet not in focus.)
Figures 5,6

Figures 7,8

Figures 9,10
Thyrsocyrtis sp. Sample 390A-6-2, 111$113 \mathrm{~cm} ; \times 140$.

Lamptonium fabaeforme fabaeforme. Sample 390A-7-1, 87-89 cm; $\times 120$.

Lamptonium fabaeforme fabaeforme. Sample 390A-6-4, 112-114 cm; × 140. 


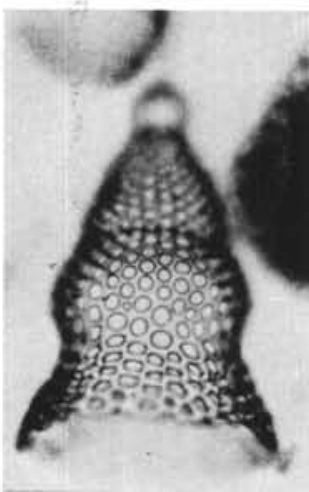

1
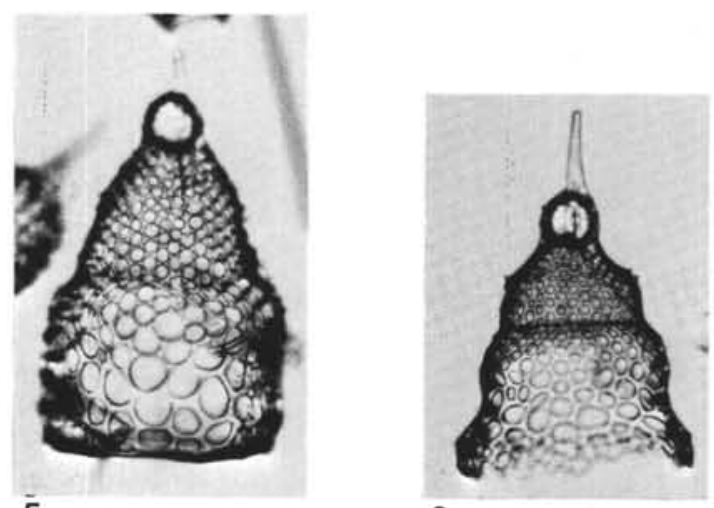

6

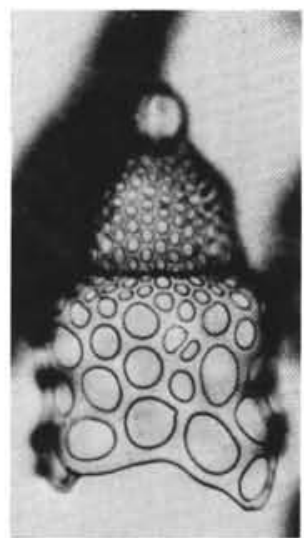

7
3

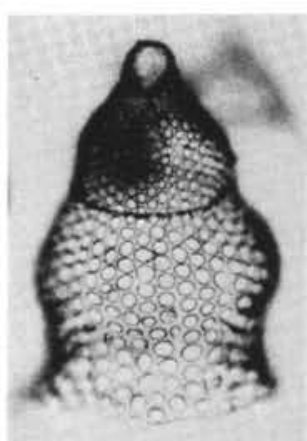

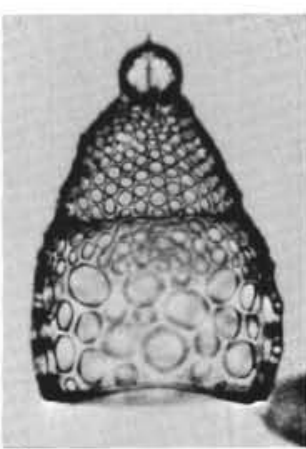

4
PLATE 7
Figures 1,2 Theocorys anaclasta. Sample 390A-6-1, Figure 6 $36-38 \mathrm{~cm} ; \times 150$.

Figure 3

Theocorys anaclasta. Sample 390A-6-1, $36-38 \mathrm{~cm} ; \times 150$.

Figure 4

Theocorys anapographa. Sample 390A$4-3,107-109 \mathrm{~cm} ; \times 160$.

Figure 5
Theocorys anapographa. Sample 390A4-1, 103-105 cm; $\times 160$.

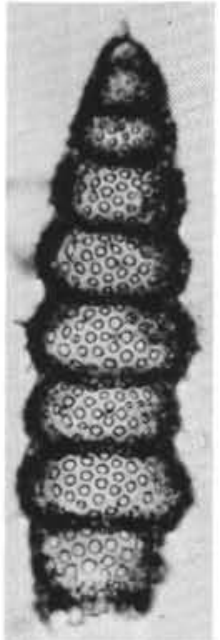

8

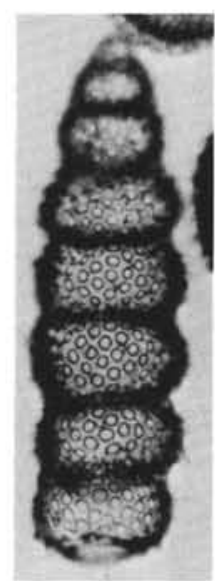

9
Theocorys acroria. Sample 390A-3-1, $141-143 \mathrm{~cm} ; \times 140$.
Figure 7

Figure 8

Figure 9
Theocorys acroria. Sample 390A-6-1, $36-38 \mathrm{~cm} ; \times 190$.

Lithocampe sp. Sample 390A-7-3, 47-49 $\mathrm{cm} ; \times 240$.

Lithocampe sp. Sample 390A-7-3, 47-49 $\mathrm{cm} ; \times 240$. 

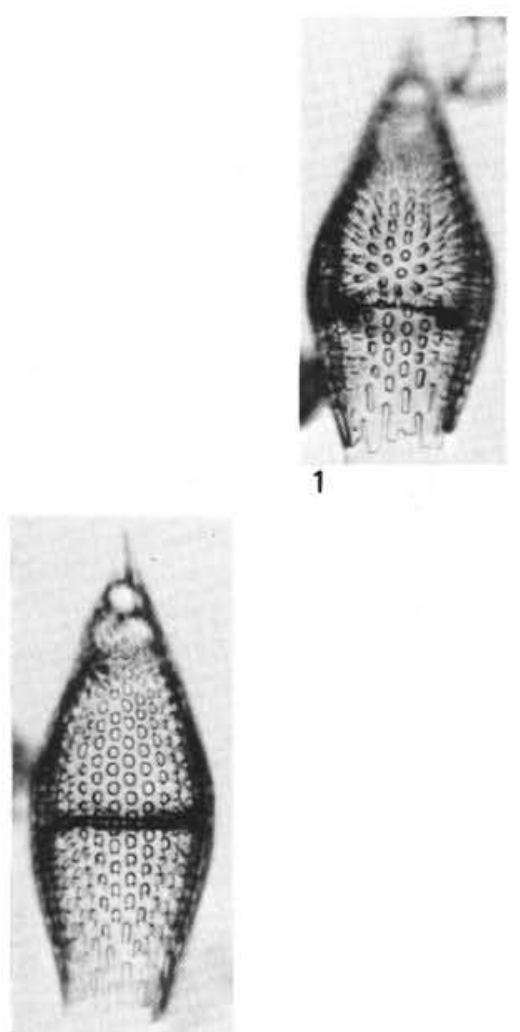

4

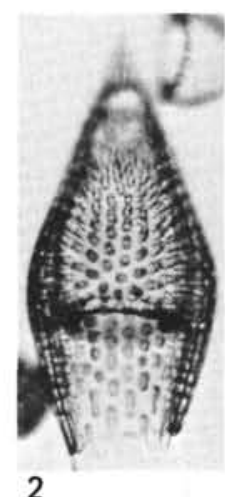

2

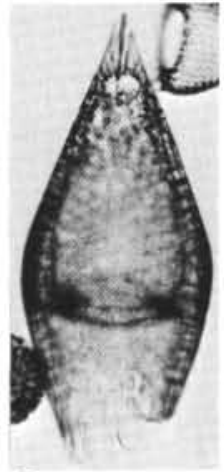

3
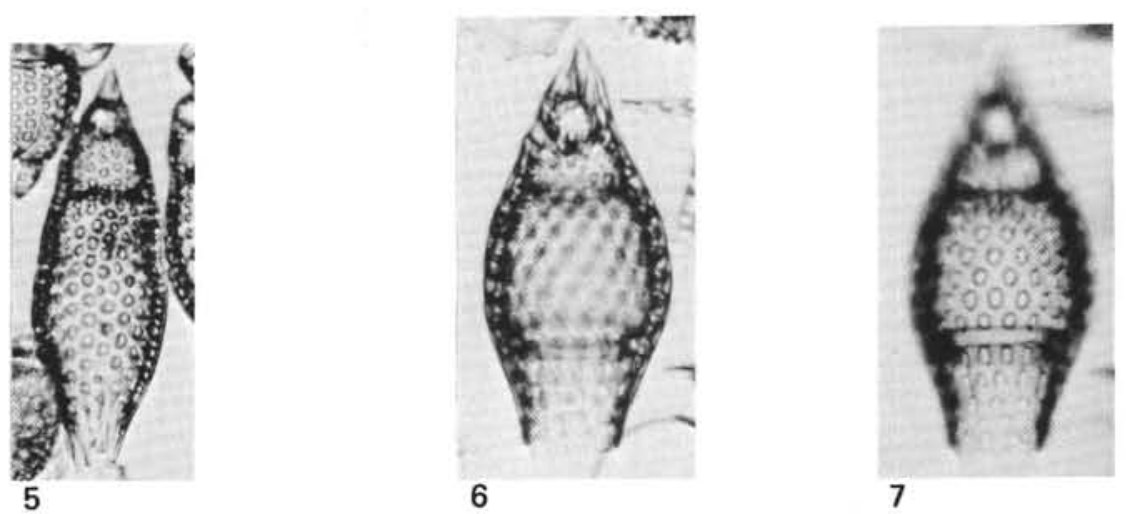

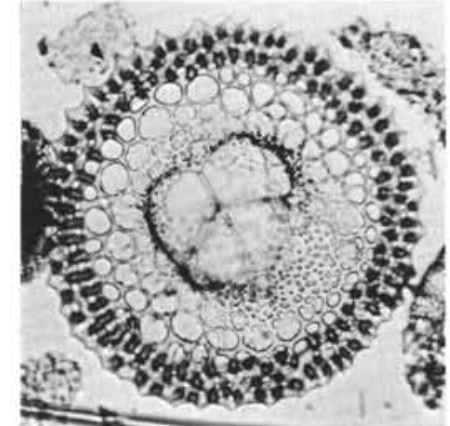

8

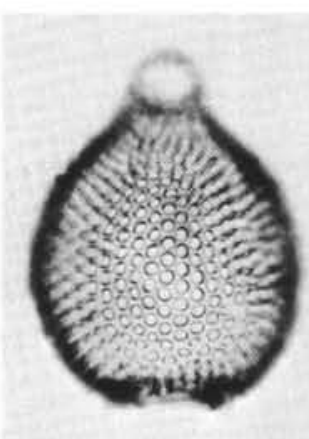

9

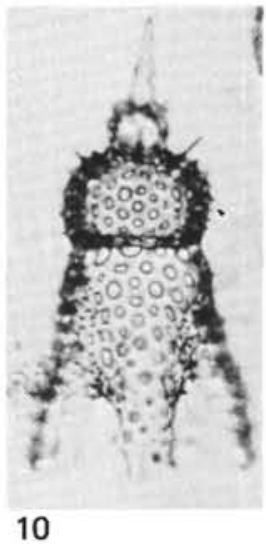

PLATE 8

Figures 1-3 Phormocyrtis sp. Sample 390A-7-2, Figures 6,7 $134-136 \mathrm{~cm} ; \times 250$.

Figure 4

Phormocyrtis sp. Sample 390A-7-4, $32-34 \mathrm{~cm} ; \times 250$.

Figure 5
Figure 8

Figure 9

Figure 10
Phormocyrtis striata striata. Sample 390A-4-1, 10-12 cm; $\times 250$.
Buryella clinata. Sample 390A-6-6, 30-32 $\mathrm{cm} ; \times 250$.

Velicucullus sp. Sample 390A-7-1, 87-89 $\mathrm{cm} ; \times 180$.

Anthocyrtoma sp. Sample 390A-5-4, $125-127 \mathrm{~cm} ; \times 170$.

Theoperid gen. et sp. indet. Sample 390A-4-1, 103-105 cm; × 200. 


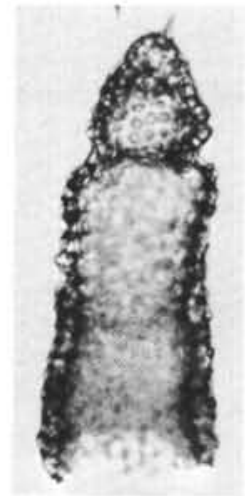

1

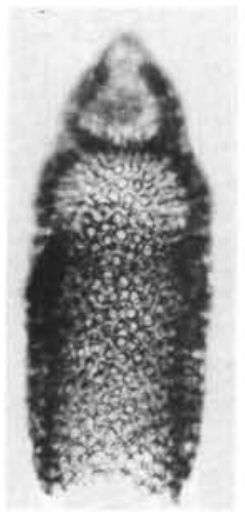

5

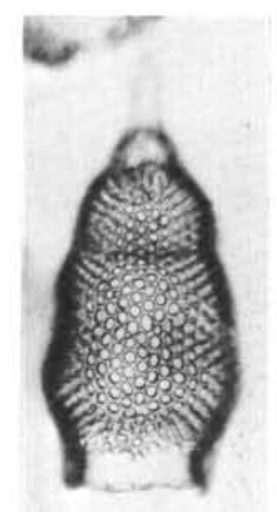

9

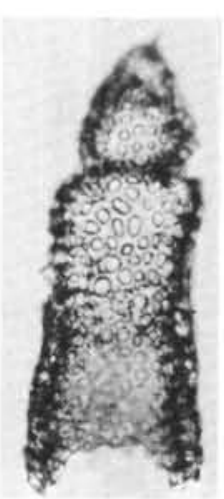

2

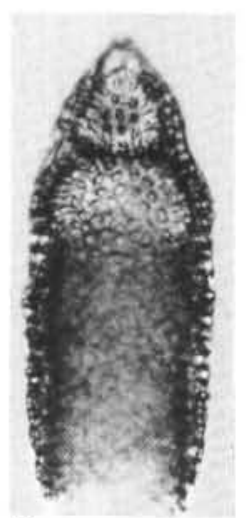

6

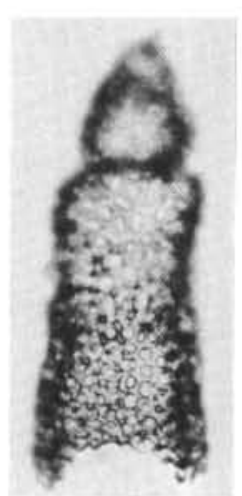

3

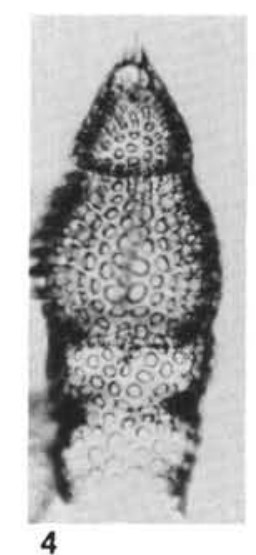

4

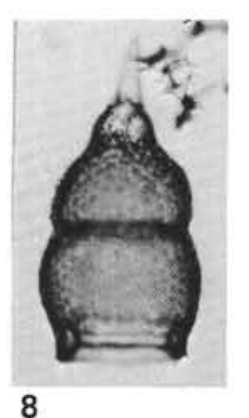

7

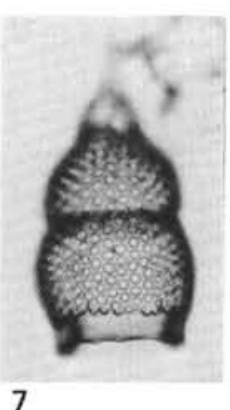

8

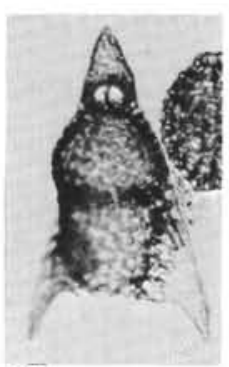

12

PLATE 9

Figures 1-3 Phormocyrtis cubensis (?). Sample $390 \mathrm{~A}-7-1,87-89 \mathrm{~cm} ; \times 150$.

Figure 4

Tricolcampe vitrea (?). Sample 390A-7-3, $140-142 \mathrm{~cm} ; \times 170$.

Figures 5,6 Phormocyrtis cubensis. Sample 390A-7- Figure 12 $4,32-34 \mathrm{~cm} ; \times 150$.
Figures 7,8

Figure 9

Figures 10,11
Theocotyle cryptocephala cryptocephala. Sample 390A-6-3, 114-116 cm; × 150.

Theocotyle cryptocephala nigriniae. Sample 390A-6-3, 114-116 cm; × 240 .

Theocotyle cryptocephala nigriniae. Sample 390A-7-1, 87-89 cm; $\times 240$.

Theoperid gen. et sp. indet. Sample 390 A-3-4, 131-133 cm; $\times 160$. 


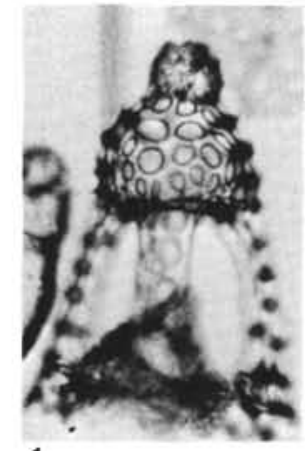

1

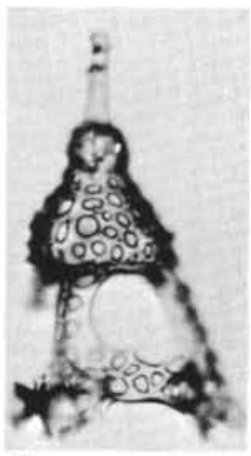

4
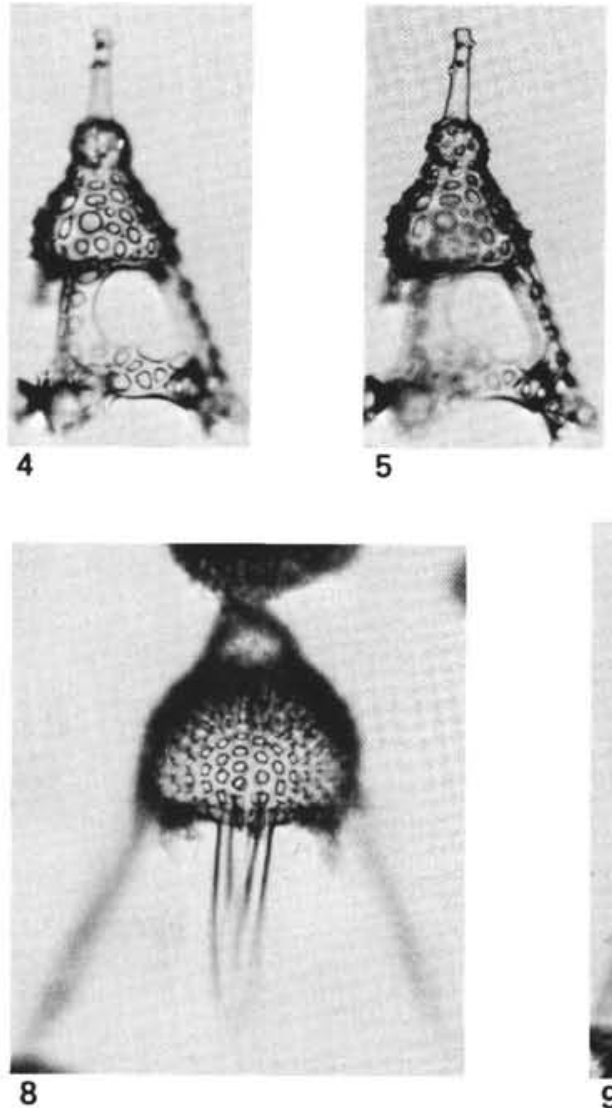

5
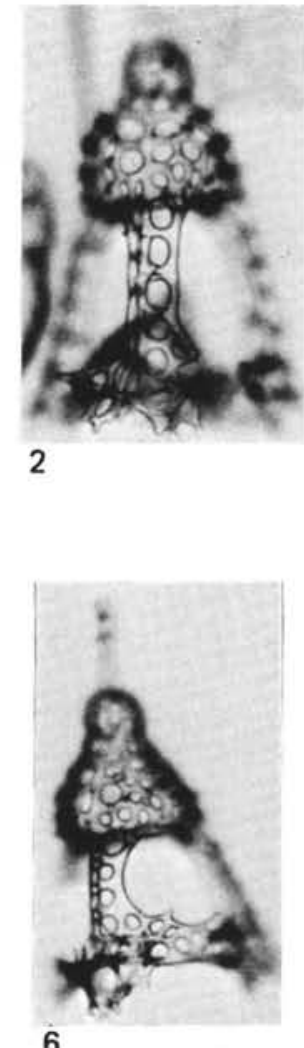

6

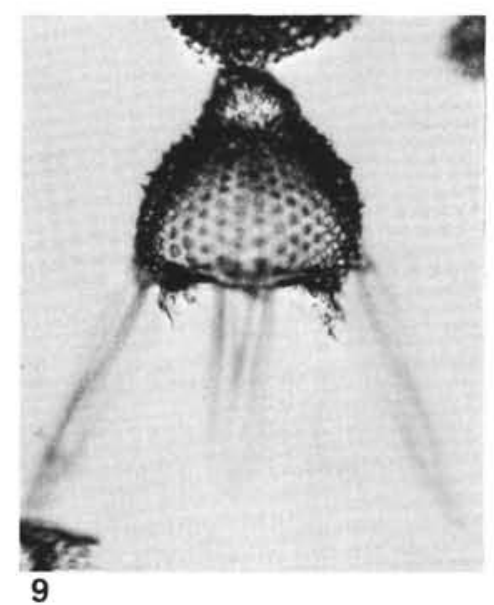

PLATE 10

Figures 1-3

Bekoma (?) sp. Sample 390A-7-3, 47-49 $\mathrm{cm} ; \times 150$.

Bekoma (?) sp. Sample 390A-7-2, 49-51

$\mathrm{cm} ; \times 150$.
Figure 7
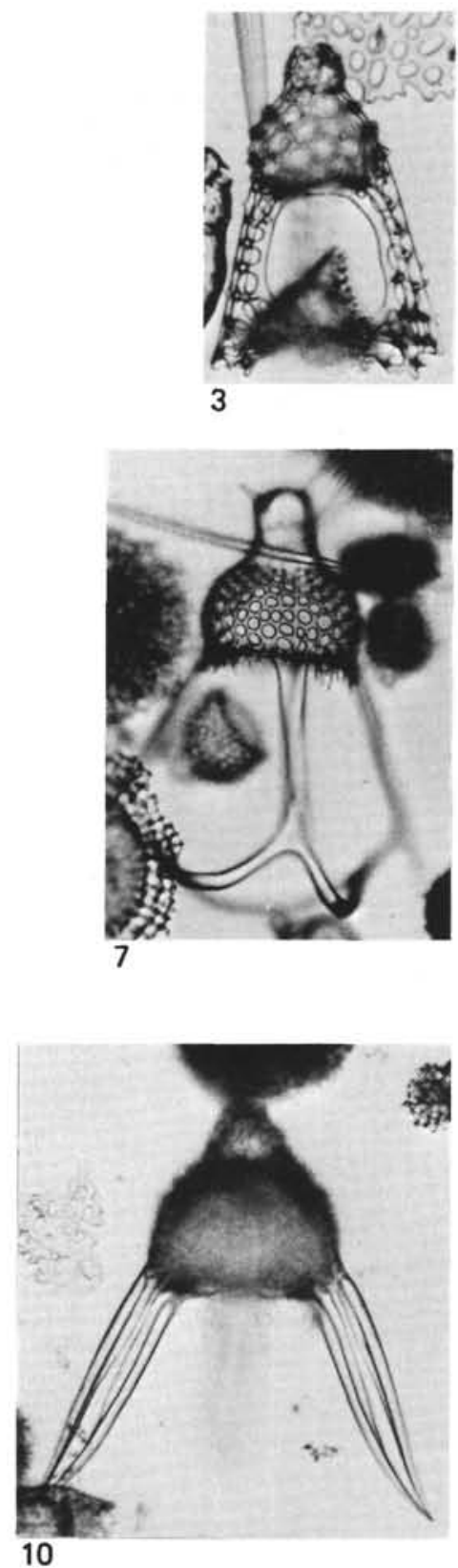

Bekoma campechensis. Sample 390A-2-2, $107-109 \mathrm{~cm} ; \times 150$.

Figures 8-10

Lychnocanoma sp. Sample 390A-6-2, $111-113 \mathrm{~cm} ; \times 160$. 


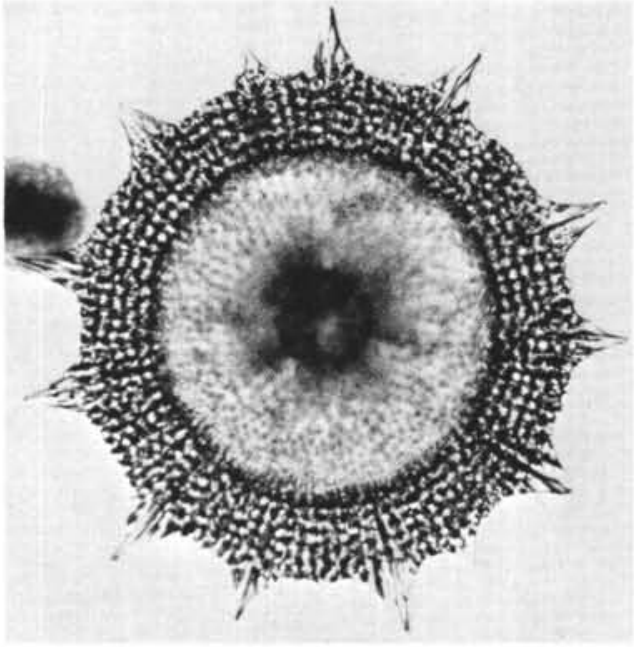

1

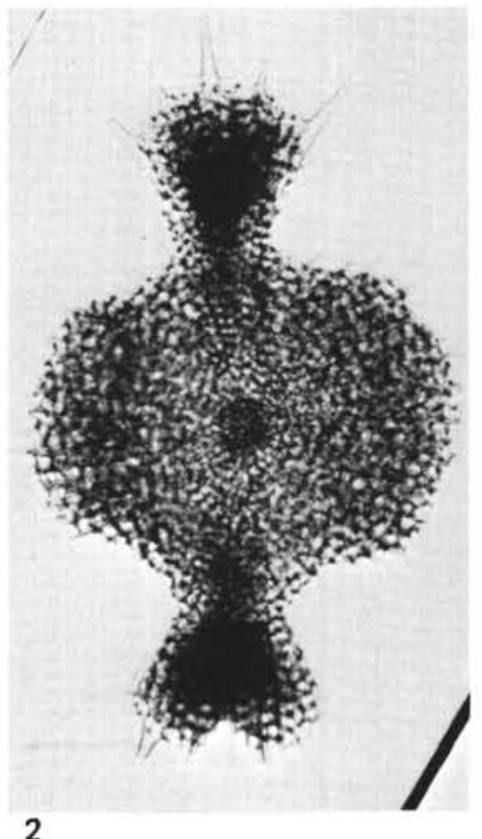

2

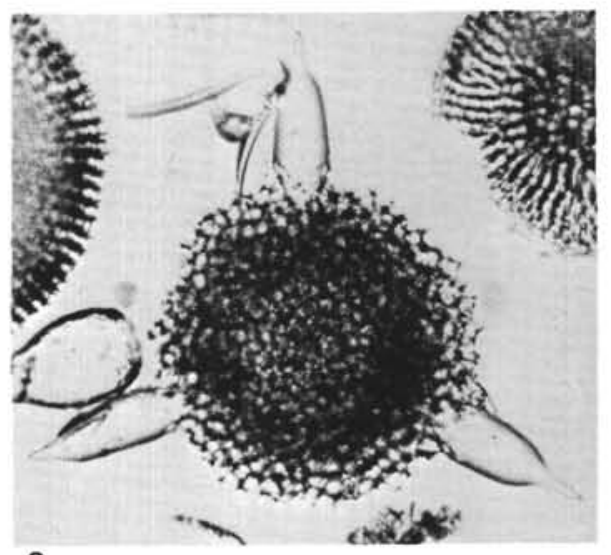

3

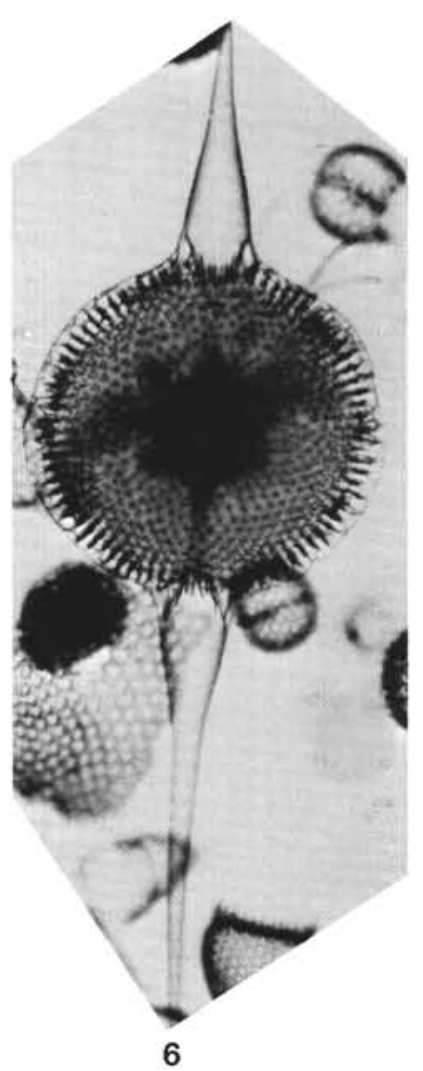

Figure 1

$$
\text { Lithocyclia ocellus group. Sample }
$$
390A-4-2, 103-105 cm; × 260.

Figure 2

Amphicraspedum murrayanum. Sample 390 A-7-1, $87-89 \mathrm{~cm} ; \times 150$.

Figure 3
PLATE 11

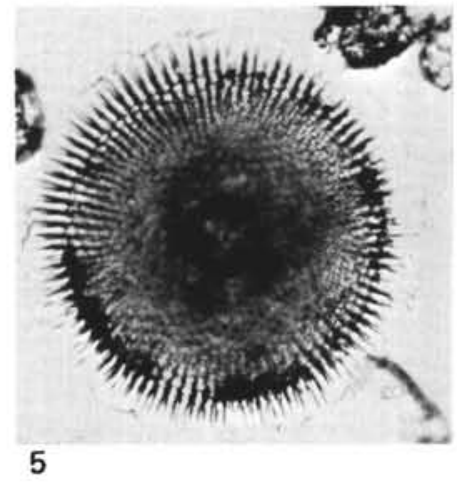

Figure 4

Figure 5

Figure 6
Spongodiscus rhabdostylus. Sample 390A-4-1, 103-105 cm; × 170. 